University of Florida Levin College of Law

UF Law Scholarship Repository

\title{
Capital Offense: The SEC's Continuing Failure to Address Small Business Financing Concerns
}

Stuart R. Cohn

University of Florida Levin College of Law, cohn@law.ufl.edu

Gregory C. Yadley

Follow this and additional works at: https://scholarship.law.ufl.edu/facultypub

Part of the Securities Law Commons

\section{Recommended Citation}

Stuart R. Cohn \& Gregory C. Yadley, Capital Offense: The SEC's Continuing Failure to Address Small Business Financing Concerns, 4 N.Y.U. J. L. \& Bus. 1 (2007), available at http://scholarship.law.ufl.edu/ faculty/pub/248 


\title{
NEW YORK UNIVERSITY \\ JOURNAL OF LAW AND BUSINESS
}

\begin{tabular}{llc}
\hline \hline VOL. 4 & Fall 2007 & No. 1 \\
\hline \hline
\end{tabular}

\section{CAPITAL OFFENSE: THE SEC'S CONTINUING FAILURE TO ADDRESS SMALL BUSINESS FINANGING CONCERNS}

\author{
Stuart R. Cohn and Gregory C. Yadley*
}

Despite years of criticism from small business advocates, the Securities and Exchange Commission has made little effort to ameliorate the severe burdens on small companies seeking to raise capital in compliance with the Securities Act of 1933 and SEC regulations. Substantial SEC attention has been given in recent years to improving the capacity of large, publiclyheld companies to market securities, but smaller companies have suffered from less-than-benign neglect. Responding to this concern, the SEC recently adopted several proposals, and has others pending, aimed at small business financing. These proposals and adoptions, while modestly helpful, fall far short of addressing the capital formation problems caused principally by SEC regulation and interpretations. In this article, the authors examine the principal hurdles facing small businesses seeking to raise capital under the securities laws, analyze the background and potential bases for the current regulatory regime, offer a critique based upon the twin goals of protecting

* Professor Stuart R. Cohn is the Gerald Sohn Research Scholar at the Levin College of Law, University of Florida and Associate Dean of International Studies; Honours Degree in Jurisprudence, Oxford University, LL.B. Yale Law School. Gregory C. Yadley is a former Branch Chief of the Securities and Exchange Commission and is a partner in the Tampa law firm Shumaker, Loop \& Kendrick, LLP; J.D. George Washington University. Mr. Yadley is currently Chair of the American Bar Association Business Law Section Subcommittee on Small Business Issuers and Adjunct Professor, Levin College of Law, University of Florida. 
investors and providing meaningful financing opportunities for smaller businesses and set forth reform recommendations.

Introduction: The Gulf Between SEC Rhetoric and ACTION ........................... 3

I. Part I: Making It Tough on Small Business .. 5

A. The Impracticality of a Registered Offering ...... 7

B. The Challenge of Meeting Registration Exemption Conditions............................ 10

II. Part II: The Evolution of Registration

ExEMPTIONS ........................ 15

A. In the Beginning: The 1933 Securities Act ..... 15

1. The Intrastate Exemption: Section $3(a)(11)$

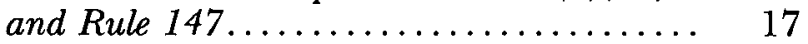

2. The Private Offering Exemptions: Section 4(2) and Rule $506 \ldots \ldots \ldots \ldots \ldots \ldots \ldots \ldots . \quad 19$

3. The Accredited Investor Exemption: Section

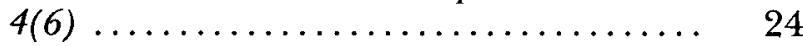

B. Regulatory Exemptions: Employing Section 3(b) Authority ......................... 24

1. The Golden Years: 1933-1953 .......... 25

2. Tightening the Screws............... 28

3. The SEC's August 2007 Proposals ........ 30

III. Part III: Putting on The SQueeze: The

Problematic Federal Exemption

Requirements ......................... 35

A. Advertising and Solicitation .............. 36

B. Numerical Limitations .................... 43

C. Integration......................... 47

D. Aggregation ....................... 52

E. Potential Loss of Exemption through Resales..... 54

F. Lack of Coordination with State Laws ......... 58

G. Unregistered Brokers and Exempt Offerings...... 61

IV. Meanwhile, Back At the Ranch: The SEC's Enigmatic Silence .................... 63

A. Seeking Justification for Commission Inaction.... 67

1. The Commission May Believe that Current Regulations are Adequate to Address the Capital Formation Problems of Small Businesses ...................... 68

2. The Commission May Be Concerned That Modifications to Existing Limitations Would 
Undermine Investor ProtectionLooking at

Some Comparative Foreign Exemptions .......

3. The Commission May Believe that

Modification of Federal Exemptions Would Be

Ineffective in Light of State Regulations..... 74

V. Recommendations for REFORM............. 80

A. Where We Are Today-In Need of Rational Regulation......................... 80

B. Reform Recommendations............... 81

1. Task Force on Small Business Capital

Formation ........................ 81

2. Recommendations for Specific Areas of

Concern ........................... 82

VI. Conclusions .......................... 85

\section{Introduction: The Gulf Between SEC Rhetoric AND ACTION}

"Small businesses pump billions into the economy. They are, in many ways, what makes America great. It's the SEC's job to see to it that small business has better access to cheaper capital on the most competitive terms possible, and we aim to do just that. We're on your side - and we're proud to be your partners."

[SEC Chairman Christopher Cox's Opening Remarks to the SEC Government-Business Forum on Small Business Capital Formation, Washington, D.C., September 29, 2006]

The track record of the Securities and Exchange Commission ("SEC" or the "Commission") on small business capital development has been decidedly at odds with Chairman Cox's above-quoted remarks about the SEC's "partnership" with small business advocates. The Small Business Forum, mandated by Congress as an annual SEC event, ${ }^{1}$ has resulted in 25 years of repeated and strongly-worded recommendations from small business advocates to lessen the SEC's regulatory bur-

1. An annual conference between the SEC and representatives of small business interests is mandated by the Omnibus Small Business Capital Formation Act of 1980, Pub. L. No. 96-477, \$ 80c-1, 94 Stat. 2292, 2293 (1980). The Report from each conference, prepared by SEC staff, contains reform recommendations proposed by conference participants. Reports from each of the annual conferences can be accessed at http://www.sec.gov/info/ smallbusiness/sbforumreps.htm. 
dens on raising capital. Yet, with rare exception, the SEC has turned a deaf ear to the Forum's recommendations and concerns. The SEC's participation in the Annual Forum is less a "partnership" than a sad twist on the Caesarian boast, "we came, we listened, we rejected." SEC initiatives in recent years have focused principally on easing regulatory requirements for registration of securities by publicly-traded companies. Precious little attention has been given to the more numerous and difficult concerns faced by small companies seeking to raise capital through exemption from registration. After years of neglect, the SEC in August 2007 took its first significant steps to demonstrate its commitment to supporting small business capital formation by proposing several rule changes regarding limited offering exemptions. ${ }^{2}$ Unfortunately, the proposals, discussed below in Part $\mathrm{II},{ }^{3}$ offered modest reform at best and failed to address the most significant regulatory barriers to capital formation.

SEC Commissioners and staff are well aware of the substantial regulatory burdens imposed on small businesses and the concerns emanating from such burdens. The 2005 Final Report from the Small Business Forum stated that "the SEC should issue a concept release on small business capital formation with a view to improving the utility of small business securities registration exemptions. . .." 4 There was nothing novel about this recommendation. The 1996 Report recommended "a bottom up review of the Securities Act and the Securities Exchange Act as they relate to the access of capital for small businesses." 5 Recommendations for modification or elimination of technical exemption requirements are peppered throughout the over two decades of Forum Reports. SEC staff unquestionably hears similar concerns in securities law confer-

2. Revisions of Limited Offering Exemptions in Regulation D, Securities Act Release No. 8,828, 2007 SEC LEXIS 1730 (Aug. 3, 2007). The comment period ended October 9, 2007. Although the comment period ended October 9,2007 , as of February 2008 no further action had been taken. It is unclear whether the proposals will be adopted substantially as proposed.

3. See infra text accompanying notes 85-97.

4. Final Report of the 24th Annual SEC Government-Business Fo. RUM ON SMALl Business Capital Formation (2005), available at http://www. sec.gov/info/smallbus/gbfor24.pdf.

5. Final Report of the 16th Annual SEC Government-Business Forum on Small Business Capital Formation (1997), available at http://www. sec.gov/info/smallbus/finrep15.txt. 
ences, discussions with small business representatives and counsel, and through the SEC's Office of Small Business, created within the Division of Corporate Finance for the purpose of considering small business rulemaking initiatives.

The mystery is why the SEC has been so non-responsive to the crescendo of small business concerns. ${ }^{6}$ This article will examine those concerns, SEC responses, policy considerations relevant to the easing of exemption requirements, and reform proposals that may enlarge the capital raising opportunities for small businesses consistent with investor protection. In Part I, we will discuss the impracticality of the registration process for small businesses and briefly describe the principal problems facing small businesses seeking to raise capital under registration exemptions. Part II will examine the evolution of legislative and regulatory registration exemptions. Part III will critique the adequacy of such legislative and regulatory responses. Part IV will examine the SEC's reluctance to expand exempt offering opportunities and offer some comparative examples from other developed economies. Part V will conclude with reform proposals that we believe are consistent with the investor protection policies underlying the Securities Act of 1933.

I.

\section{Part I: Making it Tough on Small Business}

The federal securities laws and their state counterparts ${ }^{7}$ can be reduced to two general requirements for issuers: (1)

6. It would not be fair to say that the Commission has not been mindful of small business concerns. Recent amendments to regulations that allow "free writing" prospectuses and create safe harbors for pre-registration communications have included provisions for small, non-publicly held companies. The SEC has also extended the eligibility to use the Form S-3 registration statement, allowing for shelf registration of potential securities offerings, to companies regardless of the size of their public float, although limiting eligibility to issuers who have a class of securities registered on a national securities exchange. Revisions to the Eligibility Requirements for Primary securities Offerings on Forms S-3 and F-3, Securities Act Release No. 33-8878, 2007 WL4553468 (Dec. 27, 2007). However, none of the regulatory adoptions have gone to the heart of the problem faced by small businesses in raising capital under either the enormously costly registration process or through technically difficult exemptions.

7. Congress chose not to preempt state securities laws when it adopted the 1933 Securities Act. To the contrary, section 18 of the Act specifically 
register all offers and sales of your securities unless an exemption from registration is available, and (2) tell potential investors the complete truth about your business and the security being offered. Unfortunately, these simple admonitions are not easily translated into workable regulations. In reality, raising small amounts of capital is fraught with difficulty. The irony is that, for both practical and legal reasons, it is easier for a medium-sized company to raise $\$ 50$ million than for a small company to raise $\$ 500,000$. While there are numerous exemptions from registration theoretically available for a small offering of securities, the hurdles for compliance with registration exemptions are legion.

Current securities regulation is having trouble coming to grips with the transformations generated by the information explosion over the past 25 years. Through the internet and modern communications devices, an issuer can, in real time and with no incremental cost, tell its story to literally millions of potential investors. Those investors have access to nearly unlimited information in selecting among potential investments. The amount of available information, the speed with which it is communicated and the globalization that brings interested parties together continues to increase. Accelerating advances in technology make the registration process set out in the 1933 Securities Act both quaint and obsolete. The laborious and lengthy process of paper registration statements, physical drafting sessions with dozens of participants and successive nights at printing companies are largely gone. The SEC played catch-up to the new world of communications with the Securities Offering Reform rules in $2005 .{ }^{8}$ However, the 2005 reforms dealt principally with communications prior to and during registered offerings and, for the most part, benefited only

retained state jurisdiction over securities offerings. Section 18 was amended in 1996 by the National Securities Markets Improvement Act (NSMIA), Pub. L. No. 104-290, 110 Stat. 3416,3417 (1996) by removing from state registration requirements the offering of "covered securities," a defined term that, for purposes of smaller companies, principally relates to Rule 506 offerings. The Commission is authorized to define a class of "qualified purchasers" for whom state registration would also be preempted, but the Commission has not acted to date to create this defined class. State law continues to be fully applicable to "covered securities" offerings with regard to enforcement of disclosure violations.

8. Securities Offering Reform, Securities Act Release No. 8,591, 2005 WL 1692642 (Aug. 3, 2005). 
large companies. For "well-known seasoned issuers," the federal securities registration process now conforms to the realities of modern commerce and communication, but there has been little trickle-down effect for smaller companies.

Even more disappointing, the SEC has hardly addressed the patchwork of exemptions from registration, much less updated them to accommodate the changes in technology and communications that led to the streamlined registered offering process for larger issuers. The prohibition on general solicitation, the archaic regulation of professional intermediaries and the lack of uniform federal and state regulation together conspire to emasculate the benefits of technological change. Instead of harnessing the powerful forces of communications and globalization, smaller issuers are forced to contend with the legacy of disparate and paternalistic regulation.

\section{A. The Impracticality of a Registered Offering}

The twin imperatives for smaller businesses attempting to grow are time and money. No matter how good the idea, how promising the new product, or how valuable the process improvement, development funds are a constant necessity. Driven by passion and hope, small businesses are incubators of scientific and technological advance. The amount of money needed to achieve new plateaus of success is often relatively small but the margin for error is slim and the need for funds immediate. The challenge is to obtain investment capital quickly and efficiently. Pursuing the clear regulatory path - a registered public securities offering - is not feasible for most small companies. ${ }^{9}$ The time, delay and expense of a registered

9. In December, 2007, the SEC eliminated Forms SB-1 and SB-2 applicable to small business registrations. Smaller Reporting Company Regulatory Relief and Simplification, Securities Act Release No. 33-8876, 2007 WL 4440393 (Dec. 19, 2007). All registration must now be accomplished on Form S-1, the basic registration statement form. The so-called "scaled disclosure requirements" previously set forth in the Forms SB and Regulation S-B are now incorporated into revised Form $S-1$ requirements and Regulations $S-$ $\mathrm{K}$ and $\mathrm{S}-\mathrm{X}$, the basic disclosure and financial standards for registration statements. Companies eligible for the scaled disclosures are those with less than a $\$ 75$ million public float or non-public companies with less than $\$ 50$ million annual revenues filing an initial registration statement (an increase over the prior $\$ 25$ million standards). The Commission's professed reason for elimination of the Forms SB was to avoid "the unwarranted negative perceptions of the smaller reporting company disclosure scheme." Smaller Reporting 
securities offering are simply beyond the reach or practical levels for small companies. Under ideal conditions, a registered offering may take up to six months or longer from the time of initial preparation to the effective date. Following weeks, if not months of preparation by company counsel, accountants, and internal personnel of a draft registration statement, the SEC staff comment process on the filed draft can take several months and, during that period, market conditions may change. This could result in a lower initial offering price and fewer shares sold than anticipated. Costs and expenses of lawyers, accountants, underwriters, and other professionals will generally total over $10 \%$ of the offering amount. While a self-underwritten offering will cost less and, theoretically, can be completed in less time, results have not been positive for many non-underwritten offerings. ${ }^{10}$

While it is true that being publicly-held offers the prospect of access to the world's capital markets, creates an equity currency that can be used for growth by acquisition, and provides liquidity to investors, the hurdles to achieving publiccompany status are legion. Moreover, for small, newer companies, there is no assurance that filing of a registration statement will lead to a successful offering. There is no effective way to test the market before filing a registration statement due to the Commission's "gun jumping" rules. ${ }^{11}$ Moreover, re-

Company Regulatory Relief and Simplification, SEC Rel. No. 33-8819, 2007 WL 1975991 (July 5, 2007). Whether these changes, which are principally ones of form rather than substance, will indeed improve the public perception of small company registrations is debatable. What is not debatable is that the transformations do not alter the burdensome registration requirements. On the contrary, the Release actually increases those requirements by requiring two years of audited balance sheets rather than one year as previously mandated.

10. William K. Sjostrom, Jr., Going Public Through An Internet Direct Public Offering: A Sensible Alternative for Small Companies?, 53 FLA. L. REv. 529, 593-94 (2001) (concluding that self-directed offerings using the internet are not practical for most companies unless a company has a large affinity group, such as particular customers, who will be attracted to the offering).

11. The Commission considers a company "in registration" from the time it reached an understanding with an underwriter or a public offering is otherwise contemplated through the entire period that dealers are required to deliver copies of the prospectus to purchasers of the offered securities, which is 90-days from commencement of the offering for first-time issuers. Guidelines for Release of Information by Issuers Whose Securities are in Registration, Securities Act Release No. 5,180, 1971 WL 120474, at *1 (Aug. 20, 
gardless of the outcome of the offering, the costs of the registration process are heavily front-loaded. Accounting fees, attorney retainers, SEC filing fees, broker-dealer expenses, printing and road show costs are all incurred and become payable prior to the effective date of the registration statement.

Once public, the company is now subject to the periodic reporting obligations of the Securities Exchange Act of 1934 for at least the remainder of the first year. ${ }^{12}$ The obligations imposed on all public companies by the Sarbanes-Oxley Act of 2002 have led to substantially increased audit expense and fees of attorneys and other advisors. The addition of dedicated compliance personnel and the diversion of executive management to non-operational imperatives such as compliance, investor relations and quarterly earnings reports introduce burdens that never recede. These reporting and regulatory burdens weigh extraordinarily heavily on public-traded small businesses, prompting both administrative and legislative efforts to modify such requirements for small business issuers. ${ }^{13}$

1971). During this entire time frame the company is not permitted to engage in any activities that the Commission deems "is for the purpose of facilitating the sale of securities in a proposed offering." Id. The communication limitations during the pre-filing period have been substantially lifted for large, publicly held companies. Rule 163, 17 C.F.R. 230.163 (2007). For small and first time issuers, the SEC created a safe harbor for communications more than $\mathbf{3 0}$ days prior to the initial filing of the registration statement as long as such communications do not reference a securities offering that will be the subject of the registration statement. Rule 163, 17 C.F.R. 230.163A (2007).

12. Securities Exchange Act of 1934,15 U.S.C. $\S 78$ o(d) (1997).

13. On April 23, 2006, the SEC Advisory Committee on Smaller Public Companies, in its final report to the Commission recommended that certain smaller public companies be provided exemptive relief from the management report requirement and from external auditor involvement in the Section $\mathbf{4 0 4}$ process under certain conditions unless and until a framework for assessing internal control over financial reporting is developed that recognizes the characteristics and needs of these companies. FINAL REPORT OF THE Advisory Committee on Smaller Public Companies to the U.S. Securities and Exchange Commission (April 23, 2006), available at http://www.sec. gov/info/smallbus/acspc/acspc-finalreport.pdf. In April 2006, the U.S. Government Accountability Office issued a report entitled UNITED STATES Government Accountability Office, Committee on Small Business and Entrepreneurship, U.S. Senate, Sarbanes-Oxley Act, Consideration of Key Principles Needed in Addressing Implementation for Smaller Public Companies (April 2006). This report recommended that the Commission consider whether the currently available guidance, particularly the guidance 
The combined effect of the costs imposed by the registration process and the post-registration reporting system is generally more than sufficient to convince small businesses that financing through a registered public offering is a most undesirable course. For most small businesses, the decision whether to "go public" is, realistically, more theoretical than anything else. As a practical matter, at least for early stage financings and when $\$ 20$ million or less of capital is needed, the question is how to qualify for an exemption from registration.

\section{B. The Challenge of Meeting Registration Exemption Conditions}

Management of small businesses requiring substantial capital inputs do not want to sell more control of the business than necessary and therefore do not wish to raise money before the amounts needed are known and the funds can be put to good use. For most businesses, the precise timing and financial requirements are unknown at the outset and remain sporadic throughout development stages. While management cannot predict exactly when and for what specific purpose additional funding will be needed, it is likely that the need for each new tranche will arise quickly. After seeking the advice of securities counsel, management's hopes for relatively easy and quick access to financing methodologies are quickly deflated by warnings regarding integration of offerings, purchaser and offeree qualifications, prohibitions against advertising and solicitation, numerical limits on purchasers, and state "blue sky"

on management's assessment, is sufficient or whether additional action is needed to help companies comply with the internal control over financial reporting requirements. On December 15, 2006, the SEC extended the compliance dates for non-accelerated filers to provide management's report on internal control over financial reporting until its annual report for its first fiscal year ending on or after December 15, 2007. Internal Control Over Financial Reporting in Exchange Act Periodic Reports of Non-Accelerated Filers and Newly Public Companies, Securities Act Release No. 8,760, Exchange Act Release No. 54,942, 71 Fed. Reg. 76,580, 2006 SEC LEXIS 2922 (Dec. 15, 2006). Under the extension, a non-accelerated filer must begin to provide the auditor attestation report in the annual report it files for its first fiscal year ending on or after December 15, 2008. In February, 2008, the SEC announced that it planned to further extend the compliance date to December 15,2009 , giving time to the Commission to undertake a cost-benefit analysis of the auditor attestation requirement under Section 404(b) as it applies to smaller companies. SEC to Study Costs, Benefits, Of s. 404(b) Requirements for Small Issuers, 40 Sec. Reg. L. Rep. (BNA) 168 (Feb. 5, 2008). 
laws. Dismay turns to dejection when given an estimate of the legal, accounting and other costs to be incurred to avoid the regulatory pitfalls. In short, management of smaller businesses are faced with sometimes insurmountable obstacles in raising money in full compliance with the securities laws. We will explore in greater detail the problematic aspects of the current exemption scheme in Part III. Preliminarily we note the following regulatory hurdles:

(a) The ability to market the offered securities is severely limited. The SEC's ban on general advertising and general solicitation in private offerings under Section 4(2) of the 1933 Securities Act, and in Rules 504, 505, and 506 under Regulation D, ${ }^{14}$ not only eliminates the potential of the internet to attract investors, the ban constricts the issuer to a narrow band of potential investors with whom the issuer or its agents have a preexisting relationship.

The marketing limitations may be ameliorated if smaller companies are able to employ the services of broker-dealers. ${ }^{15}$ However, because small transactions are less lucrative than large ones, they are of less interest to broker-dealers. Companies cannot usually rely on investment firms for assistance in their smaller offerings. The work to prepare a private placement memorandum and the legal costs involved are often substantial due to the lack of sophistication and informal internal reporting systems of smaller issuers. For these reasons, the risk of assisting a small transaction is simply not worth it for the broker. This situation underscores the need to develop registration exemptions that provide practical benefits to issuers by unshackling them from the limitations of the current rules,

14. See infra text accompanying notes $99-121$, for discussion of the general solicitation and general advertising prohibitions. Those prohibitions are avoided if the issuer elects to use the intrastate offering exemption, but this exemption has substantial in-state "doing business" requirements and creates enormous risks of violation from even a single inadvertent out-of-state offer. Regulation A has no similar qualifications, but it is a modified form of registration that entails many of the time and cost factors associated with registration statements.

15. The prohibition against general solicitation does not apply to brokerdealers who solicit existing customers from a pre-determined, screened list of potential investors. See, e.g., Arthur M. Borden, Esq., SEC No-Action Letter, 1978 SEC No-Act. LEXIS 2001 (Oct. 6, 1978). 
particularly the prohibition on solicitation of potential investors.

(b) The limitation on the number of non-accredited investors may severely limit initial financing of a small business. Rules 505 and 506 limit the number of non-accredited investors under those exemptions to 35 persons. ${ }^{16}$ The numerical limitation is particularly hard on smaller companies because of the concurrent prohibition against general advertising and general solicitation. As a result, the founder of a new business is limited to an investor pool of people with whom there is a pre-existing relationship. It is unlikely that very many of these individuals will be "accredited investors" under Regulation D. Companies are likely to need to rely on a large number of small investors to meet their financial goals, yet that cannot be done under the numerical limits of these rules.

(c) The failure to properly qualify investors and potential investors could invalidate an exemption from registration. The private offering exemptions, Section 4(2) and Rule 506, impose "sophistication" and "experience" eligibility standards that substantially limit a small company's pool of potential investors. ${ }^{17}$ Rule 506 modifies this requirement by allowing "accredited investors" to be purchasers without regard to their background or knowledge and permitting non-accredited investors who lack "knowledge and experience in financial and business matters" to use purchaser representatives as their agents. ${ }^{18}$ However, these modifications, when coupled with the prohibition against general solicitation and numerical limitations, provide

16. "Limitation on Number of Purchasers: There are no more than or the issuer reasonably believes that there are no more than 35 purchasers of securities from the issuer in any offering under this Rule 505." 17 C.F.R. $\S 230.505$ (b) (ii) (2007).

"Limitation on Number of Purchasers: There are no more than or the issuer reasonably believes that there are no more than 35 purchasers of securities from the issuer in any offering under this Rule 506." 17 C.F.R. $\S 230.506$ (b) (2) (i) (2007).

Persons who qualify as "accredited investors" pursuant to Rule 501 (a) are excluded from the number of purchasers. 17 C.F.R. $\$ 230.501$ (e) (2007).

17. See infra notes 40-60 and accompanying text (discussing the private offering exemption).

18. 17 C.F.R. $\$ 230.506$ (b)(2) (ii) (2007). See infra text accompanying notes $59-60$. 
little comfort to companies that need to market their securities beyond a narrow pool of potential investors.

(d) The lack of federal/state coordination magnifies the difficulties of raising capital. Even when the issuer is able to qualify for exemption from the 1933 Securities Act, there is no guarantee, other than Rule 506, that the offering will be exempt from state securities regulation. The lack of coordination explains in large part why, for example, Regulation A, a conditional small issues exemption for offerings of up to $\$ 5$ million, is seldom utilized. State law often adds a layer of cost and delay that impedes the capital-raising process. The need to review state law adds uncertainty and expense to a small private offering, and where there are only a few known prospective purchasers in a particular state, the time and costs of investigation and state qualification may not be worth the effort.

(e) Separate financings may be integrated into a single offering and, as a result, an exemption from registration may be lost. Under the SEC's integration doctrine, ${ }^{19}$ apparently distinct, separate offerings of securities to raise needed working capital could be deemed to be part of a single, unified, "integrated" offering, thereby jeopardizing the validity of each of the separate, otherwise exempt offerings. With a small, growing business that needs financing on an ongoing basis, the possibility that two or more offerings will be integrated is real. The SEC's adoption of safe harbors for offerings that are made more than six months apart may not provide sufficient cushion to accommodate pressing capital requirements. ${ }^{20}$ The August 2007 SEC Release included a proposal to reduce the six month safe harbor in Regulation D to 90 days. The reduced time frame is a step in the right direction but does not adequately address integration concerns in light of the financing requirements of smaller companies. ${ }^{21}$

19. The integration doctrine is discussed in text accompanying notes 137-146, infra.

20. The six-month safe harbors have been adopted for Rule 147,17 C.F.R. $\$ 230.147$ (b) (2) (2007), Regulations A, 17 C.F.R. $\$ 230.251$ (c) (2)(v) (2007), and D, 17 C.F.R. $\S 230.502$ (a) (2007). There is no safe harbor for offerings under section $4(2), 15$ U.S.C. $\$ 77 \mathrm{~d}(2)(2000)$, or $3(\mathrm{a})(11), 15$ U.S.C. $\$ 77 \mathrm{c}(\mathrm{a})(11)(2000)$.

21. For a discussion of integration and the SEC proposal, see infra text accompanying note 94 . 
(f) Resales by purchasers can destroy a registration exemption. Despite the issuer's best efforts, an investor's resale of a security purchased in an exempt offering can destroy the exemption relied upon by the issuer to avoid registration. ${ }^{22}$ Although the issuer can extract strict representations from its purchasers regarding their lack of intent to transfer the security and may take other measures to avoid resales, the issuer cannot always prevent or even know about a transfer which could invalidate its registration exemption.

(g) Good faith compliance may not avoid violation. Exemption requirements are technical and strict. Failure to comply with each specified condition is likely to result in loss of the exemption. Although some exemptions contain nominal "substantial compliance" provisions, these are of little value in most instances. For example, while Rule 508 provides that insignificant deviations from a requirement of Regulation $D$ do not disqualify the exemption, the key exemption conditions of Regulation D are expressly excluded from the term "insignificant deviations." 23 Therefore, the prohibition on the use of general solicitation, the limitation on the number of purchasers, and the limitation on offering amounts all must be strictly observed and any transgression, however minor or unintended, would not be deemed "insignificant." Erroneous advice from counsel that an exemption exists or that a particular condition has been satisfied is also not a defense to a claim of violation, no matter how reasonable the issuer's reliance on counsel.

The litany of obstacles imposed by exemption conditions does not fully describe their cumulative, negative impact on small companies that have no feasible alternative to raise capi-

22. All federal exemptions except offerings under Regulation A, $\S \S 230.251-63$, and to some extent Rule 504, 17 C.F.R. $\$ 230.504$ (2007), have resale limitations that affect the validity of an issuer's exemption if purchasers resell their securities within too short a time frame or to someone who would not be an eligible purchaser in the initial offering. Resales that violate such limitations can result in the issuer's loss of its exemption despite the fact that the issuer had complied with all of the exemption's requirements. See infra text accompanying notes 152-165.

23. 17 C.F.R. $\$ 230.508$ (a) (2) (2007). Rule 508 was added to Regulation $D$ several years after the Regulation's adoption in response to concerns from attorneys that minor or inadvertent deviations from the Regulation's strict requirements could void an otherwise valid exemption. 
tal other than through an exempt process. The federal exemptions from registration have grown, been modified, interpreted and re-interpreted since the adoption of the 1933 Securities Act. The result is an impenetrable screen of technical, sometimes inconsistent, and often ambiguous patchwork of regulations that inhibit the flow of capital to developing businesses. In Part II, we will examine the historical development of registration exemptions leading to today's somewhat unhappy conglomeration.

II.

\section{Part II: The Evolution of Registration Exemptions}

The statutory and administrative provisions that regulate (or, to be more accurate, that inhibit) capital formation by small companies reflect an evolving process dating from the adoption of the 1933 Securities Act. If we limited our examination only to the current set of rules and regulations, one would be justified in asking how we ended up with such unusual and internally inconsistent provisions. To understand where we are today, we need to start at the beginning.

\section{A. In the Beginning: The 1933 Securities Act}

The 1933 Securities Act, among the first pieces of New Deal legislation, was President Roosevelt's and Congress' response to the stock market debacle of 1929 and ensuing years. Congressional hearings revealed massive instances of fraud and insider abuse that were significant factors causing one-half of the $\$ 50$ billion of securities sold to the public post World War I to become worthless. ${ }^{24}$ The hearings also evidenced the inability of state securities laws to regulate effectively the interstate sale of securities. ${ }^{25}$ State agencies had inadequate resources to regulate effectively interstate transactions. A 1933 Department of Commerce report noted that "the most effective and widely used method of evading the provisions of State

24. H.R. ReP. No. 73-85, pt. 2, at 2 (1933).

25. State securities laws, known colloquially as "blue sky laws," had been in existence since 1911, when Kansas became the first state to adopt a securities law with provisions regarding registration, licensing of sales personnel, and anti-fraud provisions. $1911 \mathrm{Kan}$. Sess. Laws 210 . Within the next decade nearly every state adopted similar provisions. 
blue sky laws consists in operating across State lines." 26 The result of the Congressional hearings was a federal registration scheme, specific disclosure requirements, and a broad menu of administrative, civil, and criminal sanctions, all administered by a single central agency. The Federal Trade Commission was the initial administering agency, until adoption of the 1934 Exchange Act and establishment thereunder of the SEC.

Section 5, the heart of the 1933 Securities Act, mandates the registration of all offers to sell securities through the use of an instrumentality of interstate commerce. ${ }^{27}$ The registration process adopted was similar to that in existence at the state level, involving a disclosure document reviewed by an administrative agency prior to any sales transactions. ${ }^{28}$ The disclosure document's content and form was not left to issuer's choice. Schedule A to the 1933 Act sets forth a precise list of 32 items to be disclosed, subject to augmentation by the Commission "for the protection of investors." ${ }^{29}$ Recognizing that registration is a time-consuming, cumbersome process, Congress provided two specific registration exemptions, the intrastate exemption in Section 3(a) (11) and the private offering exemption in Section 4(2). These were not intended to be the sole registration exemptions. Significantly, Section 3(b) of the 1933 Act authorizes the Commission to adopt additional exemptions where registration "is not necessary in the public interest and for the protection of investors." 30

26. A Study of the Economic and Legal Aspects of the proposed Federal Securities Act: Hearing on H.R. Rep. No. 4314 Before the H. Comm. on Interstate \& Foreign Commerce, 73rd Cong. 87, 100 (1933).

27. Securities Act of $1933 \S 5,15$ U.S.C. $\S 77 e$ (c) (2000).

28. A principal difference between the federal and state registration schemes is the lack of merit review standards at the federal level. Disclosure alone is the requirement, and the SEC has no authority, unlike many state agencies, to preclude or impose conditions on an offering that is regarded by the Commission as economically unsound. Assuming full disclosure of all risks and uncertainties attendant to an offering, federal policy places the onus on the potential investor to determine the merits. See, e.g., Thomas LeE Hazen, The Law of Securities Regulation at 130 (5th ed. 2005) ("The SEC does not review the merits of the registration statement and the offering. Rather, in reviewing the 1933 Act registration statements. . . the focus is on the adequacy and clarity of the disclosure.").

29. Securities Act of $1933 \S 10$ (c), 15 U.S.C. $\S 77 j(c)$ (2000).

30. Securities Act of $1933 \S 3$ (b), 15 U.S.C. 77c(b) (2000). 


\section{The Intrastate Exemption: Section 3(a)(11) and Rule 147}

The statutory intrastate exemption applies to:

- any security

- which is part of an issue

- offered and sold only to residents within a single state or territory

- by an issuer resident and doing business within such state or territory. 31

The exemption is not based on any constitutional distinction between intrastate and interstate commerce. ${ }^{32}$ The exemption was premised on the belief that state securities regulators could effectively administer offerings that were limited to that state's geographic area, thus obviating the need for concurrent federal registration. The SEC noted in 1974 that the policy behind the intrastate exemption is that investors are "protected both by their proximity to the issuer and by state regulation." ${ }^{33}$ As with all exemptions, federal anti-fraud provisions continue to apply. ${ }^{34}$

31. "Any security which is part of an issue offered and sold only to persons resident within a single State or Territory, where the issuer of such security is a person resident and doing business within or, if a corporation, incorporated by and doing business within, such State or Territory." Securities Act of $1933 \$ 3(\mathrm{a})(11)$, 15 U.S.C. $\$ 77 \mathrm{c}(\mathrm{a})(11)$ (2000). The exemption was originally set forth in section 5(c) of the Securities Act of 1933, Pub. L. No. 22, 48 Stat. 74 (1933). The Securities Exchange Act of 1934, Pub. L. No. 290, 48 Stat. 881 (1934), transferred the provision to Section 3(a) (11) of the Securities Act of 1933.

32. The mandate to register offers and sales of securities is conditioned, inter alia, on the use of an instrumentality of interstate commerce. Securities Act of $1933 \S 5,15$ U.S.C. $\S 77 \mathrm{e}(2000)$. Such instrumentalities include the use of the mails, check clearinghouses, telephone, internet, and transportation facilities. If any such instrumentalities are used, registration is required, unless an exemption can be utilized, even if the offers and sales are wholly within a single state.

33. General Rules and Regulations, Securities Act of 1933, Exchange Act Release No. 5,450, 39 Fed. Reg. 2353 (Jan 21, 1974).

34. "The exemptions provided in section 3 shall not apply to the provisions of this section." Securities Act of $1933 \S 17(\mathrm{c}), 15$ U.S.C. $\S 77 q(\mathrm{c})$ (2000). Reference in section 17 is only to section $77 \mathrm{c}$ because section $77 \mathrm{c}$ purports to exclude, except as otherwise provided, the listed types of securities from all provisions of the Act, whereas the section 4 exemptions are transactional only and not otherwise exempt from any other 1933 Act provisions. 15 U.S.C. $\$ 77 \mathrm{~d}(2000)$. 
The statutory intrastate exemption is replete with ambiguous references, including "part of an issue," "residents," and "doing business." Given these ambiguities, the exemption's parameters have been developed principally through SEC interpretive releases, no-action letters, and judicial interpretations. A 1961 SEC Release attempted to outline objective criteria for the "part of an issue" concept, which essentially deals with whether two or more seemingly disparate offerings should be integrated as one offering, ${ }^{35}$ and SEC no-action letters and judicial decisions have sought to clarify the "doing business" requirement by mandating that a significant amount of the issuer's assets, revenues, and proceeds from the offering be utilized within the issuer's own state. ${ }^{36}$ Despite years of interpretive and judicial guidelines, substantial uncertainty remained (and still does) as to the exemption's outer boundaries. The SEC reacted to these uncertainties in 1974 by creating Rule 147, setting forth a precise set of objective standards for an intrastate exemption. Rule 147 addresses the "part of an issue" concept by creating six-month integration safe harbors and the "doing business" issue by creating a series of $80 \%$ tests for revenues, assets, and use of proceeds. The Rule contains specific residency definitions for various types of issuers and investors and provides for a 9-month period during which outof-state resales are prohibited. The Rule is not a substitute for, nor a Commission interpretation of, Section 3(a) (11). Rule 147 is an independent intrastate offering exemption issued under the SEC's Section 19 rule-making authority. ${ }^{37}$ An issuer thus has two potential intrastate exemptions and can seek relief under one or both. Failure to achieve the technical requirements of Rule 147 does not preclude the issuer from ar-

35. See Exemption for Local Offerings from Registration, Securities Act of 1933, Exchange Act Release No. 4,434, 1961 WL 61651, at*1 (Dec. 6, $1961)$. The integration doctrine is discussed in accompanying text at notes 128-137, infra.

36. See American Ind. Delivery, SEC No-Action Letter, 1973 WL 10394, at *1-2 (Jan. 8, 1973) (no-action letter under Section 3(a)(11) refused where issuer intended to use $25 \%$ of the proceeds for out-of-state business expansion); see also SEC v. McDonald Inv. Co., 343 F. Supp. 343, 344-46 (D. Minn. 1972) (income producing activities cannot be out of state unless generated by in-state activities).

37. Securities Act of $1933 \S 19(\mathrm{a}), 15$ U.S.C. $\$ 77 \mathrm{~s}$ (a) (2000) ("The Commission shall have authority ... to make ... such rules and regulations as may be necessary to carry out the provisions of this subchapter . ..."). 
guing that the more ambiguous standards of Section 3(a)(11) have been satisfied. ${ }^{38}$ Although Rule 147 and administrative guidelines have added clarity, substantial compliance difficulties remain and both the statutory and regulatory intrastate exemptions suffer from a lack of utility. ${ }^{39}$

\section{The Private Offering Exemption: Section 4(2) and Rule 506}

The nine words that comprise the statutory private offering exemption are a monument to brevity and ambiguity. The Section 4(2) exemption reads: "transactions by an issuer not involving any public offering." 40

The scant legislative history refers only to transactions "where there is no practical need for [the bill's] application or where the public benefits are too remote." 41 Congressional reports indicate that the exemption was intended for small, nonunderwritten offerings. As adopted in 1933, the provision read: "transactions by an issuer not with or through an underwriter and not involving any public offering."

38. Thus, for example, if the issuer fails to meet one of the $80 \%$ tests set out in Rule 147 with respect to the doing business requirement, issuer may nevertheless claim that it has met the more ambiguous "doing business" statutory standard, however that may be interpreted by the courts.

39. Numerous problems undercut the utility of the intrastate exemption. Rule 147, like Section 3(a) (11), continues the prohibition against offers or sales to out-of-state residents without regard to the inadvertence, mistake, or good faith of issuer. A single offer to a non-resident constitutes a violation for which there is no defense. Moreover, given the SEC's broad definition of "offer," materials or statements might be given or made to non-residents that constitute an "offer" and ipso facto void any exemption. Nor is there any "no harm no foul" concept in which an offer to, but not a purchase by, a nonresident is not a violation. The exemptions incorporate the integration doctrine, which is very problematic for small companies. The $80 \%$ tests of Rule 147 are strict, the percentage appears unreasonably high in light of today's global economy, and judicial construction of the "doing business" requirement remains both ambiguous and difficult. In addition, the exemptions regard out-of-state resales as violations by the issuer regardless of measures taken by the issuer to safeguard against such resales.

40. Securities Act of $1933 \$ 4(2), 15$ U.S.C. $\$ 77 d(2)$ (2000). This provision was initially the second clause of $\$ 4(1)$ of the 1933 Securities Act. It was renumbered as $\$ 4(2)$ in 1964, Act of Aug. 20, 1964, Pub. L. No. 88-467, 78 Stat. 580 (1964). The introductory portion of Section 4 states: "The provisions of Section 5 shall not apply to - -."

41. H.R. Rep. No. 73-85, at 5, 7, 15-16. 
The words "not with or through an underwriter" were deleted in the 1934 Exchange Act, ${ }^{42}$ a change regarded as not being substantive and simply the elimination of superfluous language. ${ }^{43}$ The ambiguity of the statutory language has resulted in a plethora of administrative and judicial efforts to clarify its meaning. Early SEC guidance was very much based on numerical limits, both as to the number of offerees, number of units offered, and total amount being raised. ${ }^{44} \mathrm{~A}$ Commission member stated in 1957 that: "[A]s a rule of thumb, the Commission has considered that an offering made to not more than 25 or 30 persons, who take the securities for investment and not for distribution, is generally a private transaction not requiring registration." 45

The relative simplicity of the private offering exemption was shattered by the Supreme Court in $1953^{46}$ in ways that are perplexing and problematic. Ralston Purina involved an annual company program offering small quantities of stock to socalled "key employees." The SEC challenged the validity of the offers on grounds that there was no registration exemption available, in particular that the number of offerees and their relative lack of knowledge about the company were incompatible with the policy of the private offering exemption. ${ }^{47}$ The SEC's argument was rejected by both the District Court and the Court of Appeals, both of which pointed out the relationship between the employer and the offerees, the lack of any formal solicitation, the limited number of shares distributed,

42. Securities Exchange Act of 1934, ch. 404, sec. 203(a), § 4(1), 48 Stat. 906 (1934).

43. H.R. Rep. No. 73-1838, at 41 (1934).

44. Letter of General Counsel discussing the factors to be considered in determining the availability of the exemption from registration provided by the second clause of Section 4(1), Securities Act Release No. 285, 1935 WL 27785 , at $* 1-2$ (Feb. 24, 1935). The generally accepted doctrine up until the 1950 s was that the private offering exemption allowed offers up to 25 persons without any other limitation. Beyond that number, one would need to look at the relationship among the parties, the number of units offered, and the manner of offering.

45. Andrew Downey Orrick, Some Observations on the Administration of the Securities Laws, 42 MinN. L. Rev. 25, 33 (1957).

46. See SEC v. Ralston Purina Co., 346 U.S. 119, 127 (1953).

47. In 1949 there had been 414 purchasers, in 1950 there were 411 purchasers, and in 1951 there were 165 before the program was halted. Purchasers lived in over 50 states and held jobs such as bakeshop foreman, production trainee, clerical assistant, and veterinarian. 
and the investment intent of the purchasers. ${ }^{48}$ The Supreme Court could have accepted the lower courts' reasoning, thus confirming the basic numerical aspect of the private offering exemption or, if the Court wanted to reverse, it could have done so solely on the basis of the large number of offerees and purchasers in the program. The number of offerees and purchasers had in fact been the principal basis for the SEC's argument. ${ }^{49}$ Instead, the Court chose to turn the Section 4(2) exemption from a relatively simple, numerically-oriented exemption into an exemption based on concepts of access to information, disclosure, and the elusive quality of being able to "fend for oneself." 50

The Ralston Purina decision spawned a cottage industry of SEC releases and judicial decisions attempting to clarify the Supreme Court's doctrinal guidelines, in particular who is an eligible offeree and purchaser, who is entitled to disclosure, how disclosure should be made, and the manner of offering. ${ }^{51}$ Courts had to give substance to Ralston Purina's elusive concept of being able to "fend for oneself," a concept that eventually settled into notions of "sophistication." However, although "sophistication" became a widely accepted element of the pri-

48. See SEC v. Ralston Purina Co., 200 F. 2d 85, 93 (6th Cir. 1952) (“... we do not think that the intra-organizational offerings of stock by the Company, unaccompanied by any solicitation, which have resulted in a limited distribution of stock, for investment purposes, to a select group . . . will frustrate or impair the purposes of the Act.").

49. Tom A. Alberg \& Martin E. Lybecker, New SEC Rules 146 and 147: The Nonpublic and Intrastate Offering Exemptions from Registration for the Sale of Securities, 74 Colum. L. Rev. 622, 625 (1974) (A. . rather than determine the case upon application of a numbers test, as was urged by the Commission . . . .). Mr. Lybecker was a member of the SEC staff.

50. "The design of the statute is to protect investors by promoting full disclosure of information thought necessary to informed investment decisions. The natural way to interpret the private offering exemption is in light of the statutory purpose. Since exempt transactions are those as to which 'there is no practical need for ... [the bill's] application,' the applicability of [Section 4(2)] should turn on whether the particular class of persons affected need the protection of the Act. An offering to those who are shown to be able to fend for themselves is a transaction 'not involving any public offering." " 346 U.S. 119, 124-25 (1953) (emphasis not in original).

51. Non-Public Offering Exemption, Securities Act Release No. 4,552, Fed. Sec. L Rep. (CCH) If 2770, at 2915 (Nov. 6, 1962) (“. . . an increasing tendency to rely upon the exemption for offerings of speculative issues to unrelated and uninformed persons prompts this statement to point out the limitations on the availability."). 
vate offering exemption, there was (nor still is) no uniformity as to its meaning. At least one Circuit has denied that a potential investor must satisfy a sophistication standard, 52 and application of this principle in the statutory exemption remains very unclear. ${ }^{53}$ The maelstrom of interpretive positions placed the viability of the private offering exemption in considerable doubt. A 1975 Position Paper by a committee of the American Bar Association stated that "judicial precedents have not been particularly helpful. . . . The courts. . . have used extremely broad dicta which, if taken literally, would leave little viability in the exemption under the statute." ${ }^{54}$ Even the Chairman of the SEC referred to the array of legislative, administrative, and judicial authorities as "[a] kind of mishmash." 55

The doubts and ambiguities created by varying Section 4(2) interpretations caused pressure to be brought on the SEC to develop objective guidelines for beleaguered practitioners and issuers. The Commission responded in 1974 with Rule 146. ${ }^{56}$ The Rule created an independent, stand-alone private

52. See, e.g., Hill York Corp. v. Am. Int'l Franchises, Inc., 448 F. 2d 680, 688 n.6 (5th Cir. 1971) (limiting the exemption to persons having a "privileged relationship with the issuer"); Lively v. Hirschfeld, 440 F. 2d 631, 632 (10th Cir. 1971) (stressing importance of examining "the particular capabilities and information had by particular persons, buyers, plaintiffs, or offerees."). But see, Doran v. Petroleum Mgmt. Corp., 545 F. 2d 893, 902 n.10 (5th Cir. 1977) ("We do not intimate that evidence of the offerees' sophistication is required in all cases to establish a private offering under Section 4(2).").

53. See 1 Stuart R. Cohn, Securities Counseling for Small and Emerging Companies, 6-20 (2007) (West Supp. 2007) ("Section 4(2) cases often involve multiple and interlocking problems of disclosure and offeree concerns. What is missing is the pure case of (1) full disclosure, (2) given to persons of ordinary backgrounds and intelligence, where (3) the exemption is challenged solely on the basis that such persons did not possess sufficient sophistication to be qualified investors.").

54. Committee on Federal Regulation of Securities, Position Papers Private Exemption under Section 4(2) of the Securities Act of 1933, 31 Bus. LAw. 483, 488 (1975).

55. See id. at 489 ("The issuer is now told that all of these factors have something to do with whether he has an exemption under Section 4(2), but he is never given a hint as to the proper proportions in the brew. The saving recipe is kept secret, a moving target which he can never be sure he has hit.").

56. Securities Act Release No. 5,487, 1974 WL 161966 (Apr. 23, 1974); 17 C.F.R. $\S 230.146$ (1975). Rule 146 was replaced in 1980 by Rule 506, 17 C.F.R. $§ 230.506$, see discussion infra Part III. 
offering exemption pursuant to the Commission's Section 19 rule-making authority. ${ }^{57}$ Rule 146 created clarity and benefits in some areas, such as the concept of an "offeree representative" to act on behalf of a potential investor who might not meet sophistication standards and the provision for alternative disclosure requirements depending upon whether the issuer was or was not a 1934 Exchange Act reporting company. Rule 146 nevertheless continued some of the most troublesome elements of the private offering exemption, such as the sophistication requirement and the rules against general solicitation and general advertising. Rule 146 also imposed a numerical limit of 35 purchasers, exclusive of a limited group of purchasers including those purchasing at least $\$ 150,000$ of the securities. ${ }^{58}$

Rule 146 was replaced in 1980 by Rule 506, adopted by the SEC as part of Regulation D. Rule 506 was a bit more issuer-friendly insofar as qualification standards focused solely on purchasers, not offerees, ${ }^{59}$ and a newly-defined type of purchaser, the so-called "accredited investor," was not counted within the numerical limit of 35 purchasers, was not required to meet any "sophistication" standard, and was not required to be given any of the otherwise obligatory disclosures. However, Rule 506 continued (i) the requirement of "sophistication" for non-accredited investors (who could employ purchaser representatives to avoid this problem), (ii) the numerical limit of 35 non-accredited investors, (iii) the integration doctrine, (iv) the potential loss of the exemption in the event of purchaser resales, and, most onerously, (v) the prohibitions against general advertising and solicitation. Indeed, Rule 506 was even more harsh regarding solicitation than Rule 146. Rule 146 permitted written communications to sophisticated offerees and purchaser representatives if accompanied by an undertaking to provide a full disclosure document upon request. ${ }^{60}$ This

57. 1933 Securities Act, 15 U.S.C. $\$ 77 \mathrm{~s}(\mathrm{a})$ (2005).

58. 17 C.F.R $\$ 230.146$ (g) (1) (1975).

59. The "offeree representative" concept adopted in Rule 146 was replaced by a "purchaser representative" in Rule 506. See 17 C.F.R. $\$ 230.146$ (1975); 17 C.F.R. \$ 230.506 (1980).

60. 17 C.F.R. $\$ 230.146$ (c) (1975) ("Neither the issuer nor any person acting on its behalf shall offer ... securities by means of any form of general solicitation or general advertising, including but not limited to the following .... (3) Any letter, circular, notice or other written communication, except 
sensible exception was eliminated from Rule 506, thus making communication to even the most sophisticated potential investor a possible violation of the anti-solicitation provisions.

\section{The Accredited Investor Exemption: Section 4(6)}

Only one statutory registration exemption, Section 4(6), has been added to the 1933 Act since its enactment. ${ }^{61}$ Section 4(6) was added as part of the Small Business Issuers Simplification Act of 1980.62 Section 4(6) authorizes offers or sales up to the Section $3(\mathrm{~b})$ limit (currently $\$ 5$ million) if made "solely to one or more accredited investors" and there is no advertising or public solicitation regarding the offering. Because Section 4(6) is subject to the same practical limitations as most of the SEC's rules, particularly the monetary limitation, qualification of investors, and the prohibition of general solicitation and advertising, Section 4(6) was not a useful exemption for small businesses when adopted and has remained of little value or consequence. ${ }^{63}$

\section{B. Regulatory Exemptions: Employing Section 3(b) Authority}

The 1933 Securities Act granted authority to the Commission to adopt additional registration exemptions where the Commission finds that: "enforcement of this title. . is not necessary in the public interest and for the protection of investors by reason of the small amount involved or the limited character of the public offering. . . ."64

that if paragraph (d)(1) of this section is satisfied as to each person the communication is directed and the communication contains an undertaking to provide the information specified by paragraph (e)(1) of this section on request, such communication shall be deemed not to be a form of general solicitation or general advertising.").

61. Securities Act of 1933,15 U.S.C. $\$ 77 d(6)$ (2005).

62. Small Business Issuers' Simplification Act of 1980, Pub. L. No. 96-477, $\S 602$, 94 Stat. 2294 (1980).

63. By 1980, when Section 4(6) was adopted, the SEC had already created Rule 146, a safe harbor for the private offering exemption. Despite Rule 146 's limitations, it gave greater leeway for companies to market their securities than did the new Section 4(6) statutory exemption. Subsequent SEC adoption of Rule 506, replacing Rule 146, slightly expanded the regulatory private offering exemption and is far more useful to issuers than Section $4(6)$, as is Rule 505 adopted in 1980 under Regulation D. Securities Act of 1933, 15 U.S.C. $\$ 77 d(6)(2005)$.

64. Securities Act of 1933,15 U.S.C. $\$ 77 c(b)(2005)$. 
The Commission's authority is limited to exemptions not exceeding the statutory ceiling set in Section 3(b). The ceiling, initially $\$ 100,000$, has been amended several times and is currently $\$ 5$ million. ${ }^{65}$

\section{The Golden Years: 1933-1953}

The Federal Trade Commission, the federal securities regulator prior to the creation of the SEC in late 1934, wasted no time in adopting exemptions for small issuers under its Section 3(b) authority. Within months of adoption of the 1933 Securities Act, the FTC issued, repealed, and reissued a set of rules establishing registration exemptions for limited stock offerings, notes and bonds secured by first mortgages, certificates of deposit, fractional undivided interests in mineral rights, and an entire set of regulations (Regulation B) regarding the offer and sale of fractional interests in oil or gas rights. ${ }^{66}$ Several exemptions were consolidated in a November 1,1933 , FTC Release ${ }^{67}$ which included a $\$ 100,000$ exemption based on the following conditions:

- cash transactions only;

- the $\$ 100,000$ limit included prior issuances within 12 months;

- no prior issuances of the same class within 12 months other than for cash;

- commissions not in excess of $10 \%$; and

65. Congress raised the section 3 (b) ceiling to $\$ 300,000$ in 1945 , to $\$ 500,000$ in 1970 , to $\$ 1.5$ million and then $\$ 2$ million in 1978 , and to $\$ 5$ million in 1980. Given the pattern of raises, and the continued demand for increased exemption opportunities, it is surprising that Congress has not raised the Section 3 (b) for over 25 years. The SEC requested that the ceiling be raised to $\$ 10$ million in 1992 but no congressional action was taken. Pressure to raise the Section 3(b) ceiling has abated by reason of the 1996 addition of Section 28 to the 1933 Securities Act which grants broad authority to the SEC to create exemptions "in the public interest" and has no monetary limit. Although the SEC is now able to develop new or modify existing exemptions for amounts in excess of the statutory Section 3(b) limit, it has elected thus far to remain within those limits with regard to capital raising exemptions.

66. A concise history of the early exemptions, initially known as Rules 202-210, can be found in J. William Hicks, Exempted Transactions Under THE Securities Act of 1933 7, $\$ \S 6: 1-3$ (2nd ed. 2007).

67. See Securities Act Release No. 66, 1933 WL 28878 (Nov. 1, 1933). 
- stock units sold for not less than $\$ 100$ each, and bond units not less than $\$ 500$.

In April 1934, the FTC added the following conditions to this exemption: 68

- a brief prospectus be given to the purchaser (other than a regulated financial institution or insurance company) describing the directors, shares, issuer's indebtedness, salaries in excess of $\$ 6,000$ per year, property transactions with any company officers or other insiders, capital assets, and royalty obligations; and

- a bold type statement on the cover of the prospectus that "This stock has not been registered with the Federal Trade Commission."

The April, 1934, Release also adopted an independent, unconditional exemption for offers not exceeding $\$ 30,000 .^{69}$ This unconditional exemption was based solely on the limited offering amount. It lasted only six years and was the last time the Commission created an unconditional exemption based on the offering amount.

In 1938, the SEC added Rule $210,{ }^{70}$ an exemption available to any issuer (other than for oil and gas interests covered under Regulation B) under the following conditions:

- sales were solely for cash;

- the $\$ 100,000$ limit included prior issuances within 12 months;

- offers and sales complied with state securities laws;

- prior to any offers, issuer filed a notification to the SEC stating the securities to be sold, the offering price, and the states in which offers will be made; and

- prior to any use, issuer filed with the SEC ten copies of any

- written communication proposed to be used at the offering

- commencement or intended to be sent thereafter to more than ten persons.

68. Securities Act Release No. 159, 1934 WL 28441 (Apr. 27, 1934).

69. See id. at *3.

70. Securities Act Release No. 1722, 1938 WL 32741 (Apr. 22, 1938). 
To summarize, within five years of the 1933 Securities Act's adoption, three independent exemptions had been created under Section 3(b) authority: ery;

(1) A $\$ 100,000$ exemption based upon a prospectus deliv-

(2) A $\$ 100,000$ exemption based upon SEC notification and compliance with state laws; and

(3) A $\$ 30,000$ unconditional exemption.

Alas, if the SEC had only maintained such simplicity in its regulations. There is not a single exemption in today's administrative panoply that provides as much freedom and leeway for small businesses. Today's set of highly technical, specialized exemptions are in stark contrast to the exemptions adopted in the early days of federal regulation.

In 1940, the SEC repealed its prior exemptions and replaced them with a single exemption under the rubric of Regulation A. ${ }^{71}$ The new exemption continued to be small business friendly. Its only principal requirement (other than the $\$ 100,000$ ceiling) was that the issuer send a letter to the nearest SEC regional office notifying the office of its intention to sell, together with any selling literature it planned to use. The notice only required the name of the issuer, its underwriter, the shares to be sold, and a brief description of the intended use of proceeds. There was no mandatory disclosure requirement for offerees or purchasers. Prior to any use, the issuer was required to file with the SEC three copies of any written communication proposed to be used at the commencement of the offering or intended to be sent thereafter to more than ten persons. Interestingly, the SEC stated that this new 1940 regulation:

shifts the Commission's administrative emphasis from the disclosure requirements of the Act to the fraud prevention provisions. The examination procedure which has been followed in the past will be abandoned. The use of a prospectus is no longer required, although any selling literature which is employed must be forwarded to the appropriate Regional office for its information. ${ }^{72}$

71. Securities Act Release No. 2410, 1940 WL 7107 (Dec. 3, 1940).

72. Securities Act Release No. 2410, 1940 WL 7107 at $* 2$ (Dec. 3, 1940). 
The policy and regulatory shift from disclosure review to fraud prevention was conducive to small business capital formation for it materially reduced technical, up front disclosure requirements that were time-consuming and costly. It also reduced the chances of technical non-compliance with exemption requirements. Unfortunately, the Commission's announced philosophy was relatively short-lived.

\section{Tightening the Screws}

The year 1953 was a dark year for small business capital formation. The first blow was a revised Regulation A that shifted the SEC's prior emphasis from simplicity to formality. ${ }^{73}$ The new Regulation required a rather full disclosure document (called the Offering Circular), complete with financial statements prepared in accordance with generally accepted accounting principles, ${ }^{74}$ filed and reviewed by the SEC in a manner similar to the filing and review of registration statements. Gone was the simple notification process. The new provisions created a form of modified registration, the benefits of which were very questionable in light of the Section 3(b) ceiling (then at $\$ 300,000$ ) and the fact that most states continued to require (as they still do) that Regulation A offerings go through the full state registration process. As noted by one then-contemporary commentator, the Regulation A procedure "has for the most part become too cumbersome and expensive for small financings in an enterprise's early years." 75

The second major blow was the Supreme Court's opinion in SEC v. Ralston Purina Co. ${ }^{76}$ The opinion and its progeny of administrative and judicial interpretations turned the Section 4(2) exemption from a relatively simple numerically-oriented exemption into an exemption based on concepts of access to

73. Adoption of Revised Regulation A, Securities Act Release No. 3,466 1953 WL 5669 (Mar. 6, 1953).

74. Financial statements for a Regulation A offering are required to be prepared in accordance with generally accepted accounting principles but are not required to be audited unless the issuer already prepares audited statements for other purposes. General Instructions, Regulation A Offering Statement (Form 1-A), at 30.

75. Julian M. Meer, The Private Offering Exemption Under the Federal Securities Act C A Study in Administrative and Judicial Contraction, $20 \mathrm{Sw}$. L.J. 503, 504 (1966).

76. Ralston Purina Co., 346 U.S. 119. 
information, disclosure, sophistication, and the elusive quality of being able to "fend for oneself." 77

With the doors of both Regulation A and the private offering exemption closing, substantial pressure was brought upon the SEC to address the capital formation problems facing smaller companies. The SEC responded by adopting Rule 257 to Regulation A in 1956, exempting offers up to $\$ 50,000$ from the public disclosure requirements of that exemption. ${ }^{78}$ Rule 257 proved to be an exemption of limited practicality, given the dual burdens of a low monetary ceiling and the continued requirement for preparation of a disclosure document filed with the SEC. The Rule 257 exemption was eliminated in 1992, the Commission noting that there had been only six Rule 257 filings in the previous three years. ${ }^{79}$

In response to continuing pressure for enlargement of registration exemptions, the SEC adopted Rule 240 in 1975 for offerings up to $\$ 100,000$ by closely-held companies, ${ }^{80}$ and Rule 242 in 1980 for offerings up to the Section 3(b) maximum monetary limit. ${ }^{81}$ These exemptions differed significantly from the pre-Regulation A exemptions by imposing enlarged, technical requirements for qualification. Although Rules 240 and 242 were eliminated and replaced in their entirety in 1982 by

77. See supra text accompanying note 50 .

78. Adoption of Revised Regulation A and the Consolidation Therein of Regulation D, Securities Act Release No. 3,663, 1956 WL 7217 (July 23, 1956). The issuer was relieved from preparing and delivering to prospective purchasers an Offering Circular but was required to submit to the SEC a statement (other than financials) equivalent to the offering circular. The $\$ 50,000$ limit was raised to $\$ 100,000$ in 1978 . Rule 257 was not available to issuers incorporated or organized within one year prior to the date of filing the notification that had not had a net income from operations or to issuers incorporated or organized more than one year prior to such date that not had a net income from operations one of the last two fiscal years.

79. Small Business Initiatives, Securities Act Release No. 6,949, Exchange Act Release No. 30,968, Trust Indenture Act Release No. 2,287, Financial Reporting Release No. 38, 51 SEC Docket 2154, 1992 WL 188930 (July 30, 1992).

80. Notice of Adoption of Rule 240 Under the Securities Act of 1933 B "Exemption of Certain Limited Offers and Sales by Closely Held Issuers", Securities Act Release No. 5,560, 6 SEC Docket 132, 1975 WL 160968 (Jan. 24, 1975).

81. Exemption of Limited Offers and Sales by Qualified Issuers, Securities Act Release No. 6,180, 19 SEC Docket 295, 1980 WL 29335 (Jan. 17, 1980). 
Regulation $\mathrm{D},{ }^{82}$ they set the stage for the detailed and onerous provisions that characterize today's administrative exemptions.

Regulation $\mathrm{D}$ is a comprehensive set of rules applicable in varying degrees to three separate exemptions contained within the Regulation: Rule 504 for offerings up to $\$ 1$ million; Rule 505 for offerings up to $\$ 5$ million; and Rule 506 (replacing Rule 146) for private offerings regardless of the monetary amount offered. Provisions applicable in varying degrees to each of the three exemptions include accredited investor qualifications, integration standards, aggregation limitations, prohibitions against general solicitation and advertising, imposition of restricted securities status, specific disclosure requirements for non-accredited investors, numerical limitations on non-accredited investors, SEC filing requirements, and "unworthy issuer" (also known as "bad boy") disqualification provisions for certain issuers. ${ }^{83}$ The apparent simplicity of each of the Regulation D exemptions is lost once one begins to engraft the other applicable portions of Regulation D. Regulation $\mathrm{D}$ remains the principal source of regulatory exemptions utilized by companies today, although statistics do not suggest widespread utilization by small companies. ${ }^{84}$

\section{The SEC's August 2007 Proposals}

In August 2007, the SEC announced a proposed series of measures "to clarify and modernize our rules to bring them into line with the realities of modern market practice and communications technologies without compromising investor protection." 85 The proposals are limited to the Regulation D

82. Regulation D - Revision of Certain Exemptions from Registration under the Securities Act of 1933 for Transactions Involving Limited Offers and Sales, Securities Act Release No. 6,389, 24 SEC Docket 1166, 1982 WL 35662 (Mar. 8, 1982). See also 17 C.F.R. $\$ \$ 230.501-06$ (1982).

83. See infra Part III for detailed discussion of the problems facing small companies by reason of these exemption requirements. tion.

84. See infra text accompanying note 203 regarding Regulation D utiliza-

85. See Revisions of Limited Offering Exemptions in Regulation D, Securities Act Release No. 8,828, 2007 SEC LEXIS 1730, at *6 (Aug. 3, 2007). The SEC had announced its intention to issue such proposals in May 2007, noting at the time that the proposals would "modernize and improve [the] capital raising and reporting requirements for smaller companies." Press Release, SEC, Proposed Modernization of Smaller Company Capital-Raising 
set of exemptions and include the following principal components:

- a new exemption, Rule 507 of Regulation D, for sales of securities to a newly defined category of "large accredited investors," for which the issuer could engage in limited advertising; ${ }^{86}$

- revisions to the accredited investor qualifications that (i) add an investments-owned standard to the current total assets and net worth standards and (ii) provide for inflationary adjustments to the earnings and assets standards; ${ }^{87}$

- a reduced integration safe harbor for Regulation D offerings from six months to 90 days; ${ }^{88}$ and

- a uniform disqualification provision for all Regulation D offerings. ${ }^{89}$

Despite the SEC's announced intention to facilitate capital-formation by smaller businesses, the August 2007 proposals fall far short of this goal. The principal proposal, Rule 507, is a small step in the right direction insofar as it will permit "limited advertising" for a defined set of "large accredited investors" investors. However, the pool of potential investors accessible by small companies is likely to be very small. "Large accredited investors" are the same entities and individuals as current accredited investors, with added qualifications. ${ }^{90}$ For

and Disclosure Requirements (May 23, 2007), http://www.sec.gov/news/ press $/ 2007 / 2007-102 . \mathrm{htm}$.

86. See id. at $* 9$ (proposed $\$ 230.507$ Exemption for Limited Offers and Sales to Large Accredited Investors). The current contents of Rule 507 of Regulation D will be moved into the proposed Rule 502(e).

87. See id. at *107-10 (proposed amendment to $\$ 230.501$ (a) Definitions and Terms Used in Regulation D).

88. See id. at *8 (proposed amendment to $\$ 230.502$ (a) General Conditions to Be Met, Integration).

89. See id. at $* 64$ (proposed $\$ 230.502$ (e) Disqualification Provisions). The proposal would modify and apply the "unworthy issuer" disqualification provisions currently found only in Rule 505 to all Regulation D offerings. This proposal is long overdue, as there seems little reason to differentiate among the exemptions with regard to application of "unworthy issuer" standards.

90. 17 C.F.R. $\$ 230.501$ (a) (5) (2007). For individual investors - the most likely group of potential investors for small companies - the current accredited investor standard under Rule 501 (a) is a $\$ 1$ million net worth (which could be joined with the individual's spouse) or an annual income in excess of $\$ 200,000$ ( $\$ 300,000$ when joined with a spouse). To qualify as a "large 
small companies with limited histories and resources, the "large accredited investor" pool of potential investors is even more constricted than the current standards for accredited investors. Indeed, the SEC noted in its Release that the pool of large accredited investors is $1.64 \%$ of U.S. households, compared to $8.47 \%$ that qualify as ordinary accredited investors. ${ }^{91}$ The pool of potential investors for the new Rule 507 exemption would therefore be approximately $80 \%$ less than the current pool of Rule 506 investors, a result that is difficult to regard as an improved marketing capacity for smaller companies even with the possibility of limited advertising.

The limited advertising provisions for proposed Rule 507 substantially mirror the bare-bones "tombstone" advertising provisions of Rule 135c applicable to unregistered offerings by public-reporting companies. ${ }^{92}$ The constraints are quite severe. The description of the business, which is the most important information for would-be investors, must be limited to 25 words. One must wonder what the chances are that a small, unknown company will pique the interest of potential investors in 25 words or less. The advertising is limited to written form. However, the issuer or issuer's agent may also provide orally or in writing additional information about the company and its offering directly to a potential investor if there is a reasonable belief that the potential purchaser is a large accredited investor. For most small companies and their agents, the

accredited investor" for Rule 507 purposes, the individual would be required to own more than $\$ 2.5$ million in investments or have an annual income of more than $\$ 400,000$ ( $\$ 600,000$ with one's spouse). The August 2007 Release also proposes to amend this qualification by inserting, as an alternative to the $\$ 1$ million net worth standard, an investments-owned standard of $\$ 750,000$. Individuals also qualify as accredited investors if they are a director, executive officer, or general partner of the issuer, without being subject to the income or asset standards. 17 C.F.R. $\$ 230.501$ (a) (4) (2007).

91. See $i d$. at $* 15$. The percentage figures were estimates based on Federal Reserve Board of Governors, Survey of Consumer Finances, 2004.

92. 17 C.F.R. $\$ 230.135$ (c) (2007) (Notice of Certain Proposed Unregistered Offerings). In addition to basic information regarding the issuer's name and address, brief description of the securities being offered and the offering amount, the notice for Rule 507 can also contain a brief description of the issuer's business, limited to 25 words, a description of "large accredited investors" and any suitability or minimum investment standards the issuer might impose. 
pool of known large accredited investors is assuredly a limited one.

A principal, important benefit granted by proposed Rule 507 is that, like Rule 506, the offering will preempt state registration and exemption requirements. "Large accredited investors" will be considered as "qualified purchasers" under Section 18(b) (3) of the 1933 Act, thereby providing "covered security" status and the resulting federal preemption of state registration and exemption laws. ${ }^{93}$ As discussed below, we believe that a much broader preemption in favor of federal exemptions should be developed. Rule 507 would add one more element to the preemption fold, but the Rule's narrow conditions and practical limitations make the preemption factor relatively unimportant to small companies.

In sum, while proposed Rule 507 adds to the panoply of registration exemptions, it will do little for companies not able to finance themselves from angel-type investors who are within the "large accredited investor" definition. The proposed Rule does not expand opportunities for companies that need to market their securities to a broad class of potential investors.

The proposed reduction of the integration safe harbor from six months to 90 days $^{94}$ is also a step in the right direction, but here, too, the step is modest and does not adequately address the financing needs of small companies. The proposal is limited to Regulation D and thus does not assuage the integration concerns relative to Section $4(2)$ or the intrastate offering exemptions. Nor does it address the aggregation concerns that apply to Rules 504 and 505. ${ }^{95}$ More fundamentally, the proposal retains the basic integration concept that can act as a major impediment to small business financing. We believe that the integration doctrine should not be applied to discrete offerings that otherwise satisfy exemption conditions. If a safe

93. August 2007 Release, proposed amendment to Rule 146, Rules Under Section 18 of the Act, defining the term "qualified purchaser" for purposes of Section 18(b) (3) of the 1933 Act to mean any large accredited investor as defined in Rule 501 ( $k$ ) of Regulation D. Qualified purchasers are within the list of "covered securities" offerings that the National Securities Markets Improvement Act of 1996 (NSMIA) preempts from state registration and exemption requirements. National Securities Markets Improvement Act of 1996, Pub. L. No. 104-290, § 18(b), 110 Stat. 3416, 3418 (1996).

94. See supra note 88 and accompanying text.

95. See infra notes 147-151 (discussion of aggregation). 
harbor time frame is deemed essential by the SEC, then the safe harbor should be reduced to no more than 30 days. ${ }^{96}$ The SEC's proposed 90-day safe harbor period effectively limits a company to one offering in a six month period. If, for example, a company sells securities on July 1, the 90-day "clean" period on each end dates from the beginning of April and stretches to the end of September. Any other securities offered or sold during that six-month period will be subject to the fivefactor integration test, a test that for small companies in continual need of working capital may well result in the integration of offerings.

The SEC's announced proposals fail to address the principal financing concerns of small companies. Nearly all existing technical requirements for registration exemptions remain in place, including prohibitions against advertising and solicitation, the integration doctrine, numerical limitations for Rules 505 and 506, and the loss of otherwise valid exemptions as a result of resales by purchasers beyond the control of issuers. ${ }^{97}$ Perhaps some comfort can be taken from the fact that the SEC has at last begun to consider capital-raising concerns of smaller businesses. Unfortunately, however, the August 2007 Release continues a long-term pattern of avoidance of addressing major problem areas.

To summarize, today's potpourri of statutory and administrative registration exemptions are as follows:

Intrastate

Section 3(a) (11)

Rule 147

Private Offering
Section $4(2)$
Rule 506

Rule 506

\section{$\underline{\text { Administrative }}$ \\ Regulation A}

Rule 504

Rule 505
Accredited Investor

Section $4(6)^{98}$

96. See infra Part V (Recommendations for Reform for recommendations on integration and other concerns).

97. The August 2007 Release not only continues the "restricted securities" status for Regulation D sales, the SEC stated that it is considering enlarging the realm by adding to the restricted securities list shares sold in a Rule 504 offering pursuant to a state-accredited investor exemption. See Revisions of Limited Offering Exemptions in Regulation D, Securities Act Release No. 8,828, 2007 SEC LEXIS 1730, at $* 75$ (Aug. 3, 2007).

98. There is an additional regulatory exemption, the so-called "California Exemption" contained in Rule 1001, that is tied to the accredited investor concept. 17 C.F.R. $\$ 230.1001$ (2007), Small Business Registration Exemption, Securities Act Release No. 7,285 [1995-1996 Transfer Binder] Fed. Sec. L. Rep. (CCH) II 85,803 (May 1, 1996). In 1996, the SEC took the 
The uninitiated may find this to be an impressive list eight distinct exemptions, and nine with the addition of proposed Rule 507. Surely a small company can find hope and relief in one or more of these exemptions. Or so one would think. That is, until examination reveals the difficulties, traps, and potential liabilities inherent in each. We now move to that examination.

III.

Part III: Putring on the Squeeze: The Problematic FEDERAL EXEMPTION REQUIREMENTS

Despite the existence of at least eight, and perhaps nine (counting the proposed Rule 507), registration exemptions, small companies are hard pressed to find an exemption consistent with their timing, financing, and marketing needs. The technical requirements within each exemption are justifiable if clearly tied to investor protection, but that connection is dubious at best and appears entirely lacking in some instances. The following is a discussion of the principal problem areas facing small companies under the current exemption scheme.

unusual step of creating a federal exemption dependent on compliance with a state exemption, in particular the California exemption set forth in section 25102(n) of the California Corporations Code. CAL. CORP. CoDE $\$ 25102(n)$ (West 1968). The California exemption is limited to $\$ 5$ million, companies must be organized in or have a majority of property, sales, payroll, and voting securities in California, sales can only be made to a qualified group analogous (but not identical) to Regulation D accredited investors, a disclosure document must be given to certain of the lower-scale qualified purchasers, and the securities are restricted on resale. The SEC announced that it will create a similar federal exemption for any state that adopts standards equivalent to California. To date no state has taken up that offer. The exemption is not viewed favorably because of such conditions as the intrastate nature of the issuer, disclosure requirements, monetary ceiling, suitability requirements, and resale limitations. Although the exemption permits a limited form of general solicitation, this factor alone has not led to adoption of similar exemptions in other states. A number of states have adopted the Model Accredited Investor Exemption. Although that state exemption does not enjoy federal status, it has fewer restrictions than the California exemption. Rule 1001 therefore has not created significant exemption opportunities for small businesses. 


\section{A. Advertising and Solicitation}

There is no greater impediment to the ability of small companies to raise capital under the securities laws than the SEC rules against general solicitation and advertising. The SEC has imposed severe limitations on marketing securities to prospective investors in private offerings under Section 4(2), ${ }^{99}$ and in Rule 504, 505, and 506 offerings under Regulation D. ${ }^{100}$ The only exemptions not subject to such limitations are the intrastate exemption and Regulation A, both of which generally require state registration if the offerings are widely marketed. ${ }^{101}$ Inasmuch as smaller companies generally seek to

99. Letter of General Counsel Discussing the Factors to be Considered in Determining the Availability of the Exemption from Registration Provided by the Second Clause of Section 4(1), Securities Act Release No. 285 Fed. Sec. L. Rep. (CCH) I 2740 (Jan. 24, 1935) (". . .transactions which are effected by direct negotiation by the issuer are much more likely to be nonpublic than those effected through the use of the machinery of public distribution.").

100. 17 CFR 230.502(c): "Except as provided in $\$ 230.504(\mathrm{~b})(1)$, neither the issuer nor any person acting on its behalf shall offer or sell the securities by any form of general solicitation or general advertising, including, but not limited to, the following:

(1) Any advertisement, article, notice or other communication published in any newspaper, magazine, or similar media or broadcast over television or radio; and

(2) Any seminar or meeting whose attendees have been invited by any general solicitation or general advertising;

Provided, however, that publication by an issuer of a notice in accordance with $\$ 230.135 \mathrm{c}$ shall not be deemed to constitute general solicitation or general advertising for purposes of this section ...."

The reference to Rule 504(b) (1) is the exception for issuers in a Rule 504 offering that has been state registered or is being made under a state accredited investor exemption. The exception noted under Rule 135(c) refers to "tombstone" type notices of unregistered offerings by companies subject to the 1934 Act reporting requirements.

101. The intrastate and Regulation A exemptions also contain marketing limitations. Intrastate offerings cannot be made, inadvertently or otherwise, to any non-resident, even if that non-resident does not become a purchaser. This harsh result is a major impediment to the use of the intrastate exemption. Regulation A allows for "testing the waters" with a limited disclosure document given to prospective investors prior to the filing of the Regulation A offering circular, but this limited form of solicitation is not allowed in most states unless the offering is first registered in that state. Proposed Rule 507 would allow a limited form of advertising to a defined group of "large accredited investors." The practical limitations inherent in proposed Rule 
raise capital through exempt rather than registered offerings, the SEC limitations on advertising and solicitation apply to the registration exemptions most likely to be utilized.

The genesis of the prohibitions against general advertising and general solicitation has two bases, both of which are reflected in the initial interpretive release on the private offering exemption, in which the SEC's general counsel discussed both the concept of "offer" and the manner of making such an offer. ${ }^{102}$ As to the former, the General Counsel opined that:

The word 'offering' in this sense should not be limited to those cases wherein a formal proposal for a firm commitment is submitted. Any attempt to dispose of a security should be regarded as an offer. ... Any such preliminary negotiations or conversations with a substantial number of prospective purchasers would, in my opinion, cause the offering in question to be a public offering. ... . ${ }^{103}$ stated:

With regard to the manner of offering, the opinion

the purpose of the exemption of non-public offerings is largely limited to those cases wherein the issuer desires to consummate a few transactions with particular persons. Consequently, I feel that transactions which are effected by direct negotiation by the issuer

507 are discussed in the text at notes 90-92. A major hidden problem with the Rule 507 advertising provision is the possibility that the issuer who is unable to find sufficient investors in a Rule 507 offering must thereafter suspend any alternative Regulation $D$ or private offering for at least six months (or three months if the Regulation D integration safe harbor is so reduced) to avoid an integration problem with respect to the prohibition against general advertising.

102. Letter of General Counsel discussing the factors to be considered in determining the availability of the exemption from registration provided by the second clause of Section 4(1), Securities Act Release No. 285 Fed. Sec. L. Rep. (CCH) II 2740 (Jan. 24, 1935). For a full discussion of the prohibitions against general advertising and solicitation, see, e.g., Stuart R. Cohn, Securities Markets for Small Issuers: The Barrier of Federal Solicitation and Advertising Prohibitions, 38 FLA. L. REv. 1 (1986); Patrick Daugherty, Rethinking the Ban on General Solicitation, 38 EMORY L.J. 67 (1989).

103. Letter of General Counsel Discussing the Factors to be Considered in Determining the Availability of the Exemption from Registration Provided by the Second Clause of Section 4(1), Securities Act Release No. 285, Fed. Sec. L. Rep. (CCH) I 2740 (Jan.24, 1935). 
are much more likely to be non-public than those effected through the use of the machinery of public distribution. ${ }^{104}$

While the quoted statements can be formally supported by statutory language, it must be asked whether the breadth of the interpretations is necessitated by investor protection concerns rather than formalistic doctrine. The starting point is the question of what constitutes an "offer" under the 1933 Securities Act. The statute defines an offer to include "every attempt or offer to dispose of, or solicitation of an offer to buy" a security. ${ }^{105}$ This definition is ambiguous at best. If one thinks in terms of contract law, an offer at common law conveys the material terms of the proposed agreement. ${ }^{106}$ An offer for contract law purposes would not include an invitation to a prospective purchaser to receive information regarding a proposed transaction. An offer implies a proposal that may be accepted. Reference to a potential transaction without delineation of the material terms or the opportunity for a unilateral, binding commitment is not an offer capable of forming ipso facto the contract terms. Although the 1933 Securities Act's use of the term "offer" could readily be interpreted in a contract sense, the SEC has interpreted the provision to encompass statements or notices that fall far short of normal contractual concepts. ${ }^{107}$ The SEC has successfully prosecuted its position in several instances, ${ }^{108}$ although all of the cases involved solici-

104. Id.

105. Securities Act of 1933,15 U.S.C. $\$ 77$ (b) (3).

106. “An offer, capable of being converted into an agreement by acceptance, must consist of a definite promise to be bound provided that certain specified terms are accepted. . . . He must not merely have been feeling his way towvards an agreement, not merely initiating negotiations from which an agreement might or might not in time result." G.C. CHESIREs \& C.H.S. FifoOT, THE LAW OF Contracr 26 (6th ed. 1964) (emphasis added).

107. Publication of Information Prior to or After Effective Date of Registration Statement, Securities Act Release No. 3,844 Fed. Sec. L. Rep. (CCH) I 3250 (Oct. 8. 1957) ("It apparently is not generally understood, however, that the publication of information and statements, and publicity efforts, generally, made in advance of a proposed financing, although not couched in terms of an express offer, may in fact contribute to conditioning the public mind or arousing public interest in the issuer or in the securities of an issuer in a manner which raises a serious question whether the publicity is not in fact part of the selling effort.").

108. Diskin v. Lomasney \& Co., 452 F.2d 871, 875 (2d Cir. 1971) (brokerdealer's written promise to sell plaintiff 5,000 shares of Continental Travel, 
tation of specific transactions that were well beyond simple advertisements or requests for further information. Imposing the protections of the securities laws on negotiations that are short of a formal contractual commitment is justifiable, for there is legitimate concern that pre-registration announcements, publicity, and notices could "condition the market for the securities that [promoters] are trying to sell." 109 This concern is the principal basis for the Commission's gun-jumping rules and mandatory "quiet period" prior to the filing of a registration statement, ${ }^{110}$ and the SEC has successfully brought remedial actions where promoters have publicized specific offering information or made value-laden judgments regarding as-yet to be registered offerings. ${ }^{11}$ However, in one of the few reported cases in this area, the Second Circuit indicated that some "line drawing" was appropriate and that the amount of information provided would be important to determine

Ltd., unaccompanied by any preliminary prospectus, if plaintiff would purchase 1,000 registered shares of Ski Park City West constituted an "offer" under the Securities Act); SEC v. Cavanagh, 155 F.3d 129, 135 (2d Cir. 1998) (negotiations for the sale of securities conditional on the closing of a merger transaction constituted an "offer"); SEC v. Commercial Inv. \& Dev. Corp. of Fla., 373 F. Supp. 1153, 1164 (S.D. Fla. 1974) (letter to existing shareholders advising of proposed public offering and asking for commitments to purchase shares prior to registration constituted an "offer"); Damson Oil Corp., SEC No-Action Letter, [1974-1975 Transfer Binder] Fed. Sec. L. Rep. (CCH) II 79,916 (July 5, 1974) (advertisement making no reference to specific offering but asking for response from readers who "want to find out more" regarded by SEC as improper first step in offering process); Gerald F. Gerstenfeld, SEC No-Action Letter, 1985 Lexis No-Act. 2790 (Dec. 3, 1985) (general advertisement by syndicator of limited partnerships asking readers to call or write for more information regarded as offer even if no current offerings exist but future ones are planned).

109. SEC v. Thomas D. Kienlen Corp., 755 F. Supp. 936, 940 (D. Or. 1991) (citing SEC brief in action against promoter of mutual fund who held meetings and passed out brochures to potential investors prior to registration).

110. See, e.g., Rule 163A, Exemption from Section 5(c) of the Act for Certain Communications Made By or on Behalf of Issuers More Than 30 Days Before a Registration Statement is Filed, 17 C.F.R. $\$ 230.163$ A (2005).

111. See, e.g., Chris-Craft Indus. v. Bangor Punta Corp., 426 F.2d 569, 574 (2d Cir. 1970) (pre-registration press release stating price of shares to be offered); SEC v. Arvida Corp., 169 F. Supp. 211, 214 (S.D.N.Y. 1958) (press conference answered reporters' questions regarding proposed offering, including proposed offering price per share); Kienlen, 755 F. Supp. at 938-39 (pre-registration notices, meetings, brochures and postcards extolling virtues of to-be-formed mutual fund). 
whether an offer has been made under the Act. ${ }^{112}$ Unfortunately, the "line-drawing" dictum has been ignored by the SEC, whose staff has concluded that even nondescript general notices of a securities offering that simply invite interested persons to apply for more information is an "offer" within the meaning of the Act. ${ }^{113}$ This SEC position, formalized in the specific prohibition in Rule 502(c) against "[a]ny advertisement, article, notice, or other communication published in any newspaper, magazine, or similar media. ..," was adopted without any findings justifying how a general announcement could "pre-condition" the market, affect investor decisions, or otherwise undermine investor protection. One is hard pressed to understand how a notice in a newspaper that a company is planning or engaged in an offering of securities, and that invites readers to request a copy of the private placement memorandum, rises to the level of an "offer" by the company, or a solicitation of an offer from an unidentified member of the public. Even if the Commission believes that the 1933 Securities Act could be read so broadly, there is no impediment to the Commission adopting a reasonable interpretation that allows limited notices and advertisements of the fact of an offering. ${ }^{114}$

112. Chris Craft Indus., 426 F. $2 d$ at 574 ("When it is announced that securities will be sold at some date in the future and, in addition, an attractive description of these securities and of the issuer is furnished, it seems clear that such an announcement provides much the same kind of information as that contained in a prospectus. ... Doubtless the line drawn between an announcement containing sufficient information to constitute an offer and one which does not must to some extent be arbitrary." (Emphasis added).

113. Damson Oil Corp., SEC No-Action Letter, [1974-1975 Transfer Binder] Fed. Sec. L. Rep. (CCH) II 79,916 (July 5, 1974) (advertisement making no reference to specific offering but asking for response from readers who "want to find out more" regarded by SEC as improper first step in offering process); Gerald F. Gerstenfeld, SEC No-Action Letter, 1985 SEC No-Act. Lexis 2790 (Dec. 3, 1985) (general advertisement by syndicator of limited partnerships asking readers to call or write for more information regarded as offer even if no current offerings exist but future ones are planned).

114. So-called "tombstone advertisements" permitted under certain SEC rules apply only to registered offerings (Rule 135) or unregistered offerings by 1934 Act reporting companies (Rule 135 (c)). There is no provision allowing limited public announcements for unregistered private or Regulation $\mathrm{D}$ offerings by non-reporting companies. 
A second major problem with the SEC's anti-solicitation doctrine is the breadth applied to the term "general solicitation." No one should dispute that a limited exempt offering should not be conducted on street corners or through subscription documents in airline magazines. But the SEC has adopted an almost equally polar position by interpreting "general solicitation" to include offers to any person with whom the issuer, or issuer's agent, has not had a prior relationship. ${ }^{115}$ To make matters worse, i.e. to further constrict the range of potential offerees, the SEC staff has stated that the pre-existing relationship must be one that provides issuer or issuer's agent with knowledge as to the offeree's sophistication or financial circumstances. ${ }^{116}$ Even if an offering is directed only to a known group of accredited investors, the anti-solicitation rules

115. See, e.g., Kenman Corp., Exchange Act Release. No. 21,962 [19841985 Transfer Binder] Fed. Sec. L. Rep. (CCH) I 83,767 (Apr. 19, 1985) (administrative proceeding finding violation of anti-solicitation rules for Section 4(2) and Rule 506 where solicitations went to persons "with no preexisting relationship to the offeror.") Id. at 87,428, n.6; Texas Investor Newsletter, SEC No-Action Letter, 1984 SEC No-Act. Lexis 1582 (Jan. 23, 1984) (mailing of over 200 brochures to broker-dealers, investment advisers, attorneys and accountants, along with statement that no offer would be made without delivery of private placement memorandum, violated anti-solicitation rules); David B.H. Martin, Jr. \& L. Keith Parsons, The Pre-existing Relationship Doctrine Under Regulation D: A Rule Without Reason, 45 WASH. \& LEE L. REv. 1031, 1044 (1988) ("The staff's interpretive letters under Rule 502(c) indicated that the staff believes a pre-existing relationship between the issuer or its agents and offerees to be an almost absolute prerequisite to avoiding general solicitation in a Regulation D offering.").

116. Mineral Lands Research \& Marketing Corp., SEC No-Action Letter, 1985 WL 55694, at *1 (November 4, 1985) ("That question concerns the application of Rule 502(c) to the Company's proposal to offer securities to persons with whom officers and directors of the Company have prior business relationships. . . . The types of relationships with offerees that may be important in establishing that a general solicitation has not taken place are those that would enable the issuer (or a person acting on its behalf) to be aware of the financial circumstances or sophistication of the persons with whom the relationship exists or that otherwise are of some substance and duration." (emphasis added)). Even if an offering is directed to persons with whom the issuer has a preexisting relationship, such as customers, that relationship might not be sufficient in the absence of investor qualification information. Tog Shop, SEC No-Action Letter, [1977-1978 Transfer Binder] Fed Sec L Rep (CCH) II 81,192 (no-action letter denied for introductory letters to selected principal customers to obtain expressions of interest in receiving offering prospectus). 
will have been violated in the absence of a pre-existing relationship. ${ }^{117}$

The SEC's proscriptions against advertising and solicitation are difficult to justify as to breadth and purpose. The statutory basis is ambiguous at best, and SEC staff interpretations have no apparent linkage to investor protection. Who or how one is approached with regard to an offering should be of little importance compared to the quality of information given to a prospective investor and the ability of that investor to understand the merits and risks of the offering. The strict prohibition against general advertising and solicitation appears to have little relationship to protecting an individual investor. If a potential investor is given adequate disclosure and has the capacity to evaluate the merits, why should the issuer be required to have a pre-existing relationship with the investor? Indeed, general advertising and solicitation are permitted for intrastate offerings, for state-registered Rule 504 offerings, for Regulation A offerings, and of course for registered offerings. In none of those instances is there any qualification as to relationship or concern regarding the investor's capacity to evaluate the offering's merits. ${ }^{118}$ Why should the limitations exist for private and Regulation D offerings? What "investor protection" goal is satisfied by demanding a pre-existing relationship to the issuer? One may even turn the tables on this requirement, suggesting that a pre-existing relationship creates a greater danger of over-reliance on the issuer's promoters, as evidenced by the affinity frauds among church groups and other organizations. ${ }^{119}$

The advertising and solicitation proscriptions have been a constant source of concern and the subject of reform recommendations expressed year after year by participants in the

117. Securities Act Release No. 6,455, 1983 WL 409415 (Mar. 3, 1983), Q. 60,1983 WL 409415 , at *1 ("The mere fact that a solicitation is directed only to accredited investors will not mean that the solicitation is in compliance with Rule 502(c). Rule 502(c) relates to the nature of the offering, not the nature of the offerees.").

118. Intrastate offerings are of course limited to state residents, but that can hardly be thought of as creating any kind of relationship qualification.

119. See, e.g. Affinity Fraud: How To Avoid Investment Scams That Target Groups, SEC Report (modified Sept. 6, 2006), available at http://www.sec. gov/investor/pubs/affinity.htm ("These scams exploit the trust and friendship that exist in groups of people who have something in common."). 
SEC's Government Small Business Forum, ${ }^{120}$ yet for 25 years the Commission has not responded to the criticism or provided a single bit of evidentiary basis that its rules are worthy of retention. The shackles placed on small businesses by these rules prevent the effective marketing of securities and place small companies under enormous risk of liability should the offering process creep even accidentally into forbidden grounds. ${ }^{121}$ While the CEO of a smaller issuer may present her business strategy and future plans to a chamber of commerce audience or a business networking forum, if she includes too much detail in the discussion of financing that growth, she may forfeit the exemption from registration. The rigidity of the exemption rules unnecessarily draws a straight line from business promotion to a potential offer of a security when the regulatory focus should be on the actual purchase of the security. The in terrorem impact of these rules hang over small companies that do not have personal acquaintance with sufficient investors to raise significant amounts of capital and are unable to interest brokers to assist in their limited scale offerings. The prohibitions choke off and invalidate ordinary and reasonable communications between entrepreneurs and potential investors and stop potentially beneficial offerings dead in their tracks.

\section{B. Numerical Limitations}

Rules 505 and 506 both impose a limit of 35 non-accredited investors. There is no limit on the number of accredited investors, but the ability of smaller companies to access accredited investors (especially given the advertising and solicitation prohibitions) and obtain substantial capital from them will often be quite limited. As a result, the ceiling of 35 non-ac-

120. See supra note 1 and accompanying text with reference to the annual SEC-sponsored forum.

121. The SEC has indicated that a single inadvertent solicitation might not violate Rule 502(c). Securities Act Release No. 6,825 [1988-1989 Transfer Binder] Fed. Sec. L. Rep. (CCH) I 84,404, at 80,047 (Mar. 14, 1989) ("if an offering is structured so that only persons with whom the issuer and its agents have had a prior relationship are solicited, the fact that one potential investor with whom there is no such prior relationship is called may not necessarily result in a general solicitation."). One wonders whether the SEC seriously considered the implicit indications arising from its reference to "one potential investor." 
credited investors can be a substantial restriction. A small company seeking to raise, for example, $\$ 2$ million through a Rule 505 offering, would need to average approximately $\$ 57,000$ per non-accredited investor, less amounts invested by accredited investors. This is a daunting task for companies that do not have ready access to accredited investors. Proposed Rule 507 does not have a numerical limitation, but that offering must be limited to so-called "large accredited investors," an even smaller group than ordinary accredited investors. ${ }^{122}$

The number 35 has no statutory basis. At one time a general notion persisted that a private offering was confined to a 25-30 person range, ${ }^{123}$ but that notion was exploded by the Supreme Court's declaration in Ralston Purina that there was no numerical test for a private offering. ${ }^{124}$ Exemptions for limited offerings adopted shortly after enactment of the 1933 legislation contained no numerical limits on purchasers. ${ }^{125}$ The 35-purchaser limitation first appeared in Rule 146, the SEC's regulatory private offering exemption adopted in $1974 .{ }^{126}$ The Commission's succinct explanation of the numerical limitation was that it was "consistent" with the limited manner of offering proscriptions as well as serving "to assure that the transaction does not involve or result in a deferred distribution." 127 How the number 35 was selected was not revealed, but the figure has remained sacrosanct to this day with regard to non-accredited investors. Violation of the numerical limitation is specifically excluded from the "insignificant deviations" provisions of Rule 508, further sanctifying this arbitrary limitation. ${ }^{128}$

122. The SEC has estimated that the proposed set of "large accredited investors" would be approximately $80 \%$ less than ordinary accredited investors as defined in Regulation D. See discussion supra note 85.

123. Orrick, supra note 45 , at 33 .

124. 346 U.S. 119 at 125 ("The Commission would have us go one step further and hold that 'an offering to a substantial number of the public' is not exempt. . . . But there is no warrant for superimposing a quantity limit on private offerings as a matter of statutory interpretation.").

125. See supra notes 66-72 and accompanying text.

126. Notice of Adoption of Rule 146, Transactions by an Issuer Deemed Not to Involve Any Public Offering, 39 Fed. Reg. 15,261 (S.E.C. May 2, 1974).

127. $I d$.

128. Rule 240 , adopted in 1975 for offerings up to $\$ 100,000$ and replaced by Regulation D in 1982, had no limitation on the number of purchasers but 
There also are a number of practical problems presented by the 35 person limitation. For example, investors routinely, for tax and estate planning purposes, desire to purchase stock in the names of their children, grandchildren, or other family members. Unless such intended beneficiaries are themselves accredited investors, which is often unlikely, or are living within the same principal residence as the investor, purchases in their names will count against the numerical limit. ${ }^{129}$ This result requires the parent or other relative to purchase all of the shares individually and to make transfers to the intended beneficiaries at a later date. Even if the SEC would not consider this two-step process as a violation of the numerical limitations, a process that requires such subterfuge has no rational justification except to stay within an arbitrary 35 person limitation. Another example involves employees who have not yet accumulated sufficient wealth to be accredited but who are key employees who want to help the company achieve success. Because of the 35 person limitation, some or all of these employees will be unable to participate as investors in that endeavor.

In fact, younger individuals are effectively foreclosed from participating in private offerings. It frequently takes a number of years until an individual is able to meet the $\$ 1$ million threshold, particularly if he or she has incurred substantial college or graduate school loans. At least in the current real estate environment, home values are unlikely to bring increased paper wealth in just a few years. No matter how well educated or able to understand the risks and merits of even a modest investment, the numerical limit severely limits the number of persons able to participate in the offering. One might say, paternalistically, that such younger investors should invest their savings in the public markets. To the contrary, the individual contact between investor and issuer in a private offering presents perhaps a better tradeoff. The purchaser of a traded security must rely entirely on the public disclosures of the issuer. The purchaser of a security in a private placement is entitled to ask for, and receive, from the company's officers infor-

there was a limit of 100 beneficial holders of the issuer's securities. 17 C.F.R. $\S 230.508$ (2007).

129. Rule 501(e)(1) of Regulation D excludes from the calculation of the number of purchasers "[a]ny relative, spouse or relative of the spouse of a purchaser who has the same principal residence as the purchaser." 17 C.F.R. $\S 230.501$ (2007). 
mation that the investor deems important. Privity is created with such disclosures, and the personal liability of company officers who relate information provides a significant protection to the investor.

As with its other requirements, the SEC's numerical proscription should be subjected to analysis in terms of investor protection. In this light, the numerical limitation appears arbitrary and inconsistent with regulatory standards. Rules $\mathbf{5 0 5}$ and 506 both require that disclosure documents be provided to non-accredited investors, ${ }^{130}$ that such purchasers be given the opportunity to ask questions and receive answers, ${ }^{131}$ that they be apprised in writing of any material information given to accredited investors not otherwise disclosed, ${ }^{132}$ and that they be advised specifically of resale limitations. ${ }^{133}$ Given this full disclosure context, it is difficult to understand what investor protection goals are achieved by limiting the number of purchasers. The SEC did not adopt numerical limitations for its Rule 147, Rule 504 and Regulation A exemptions, although neither Rule 147 nor Rule 504 contain mandatory disclosure requirements. Yet, for Rules 505 and 506, which have substantial disclosure provisions, the SEC severely limits the number of nonaccredited purchasers.

Section 3(b) of the 1933 Act authorizes the SEC to issue regulatory exemptions if registration is not necessary "by reason of the small amount involved or the limited character of the public offering." 134 Even if this provision arguably justifies a numerical limitation, the number 35 is extraordinarily low and seems entirely inconsistent with the fact that there is no numerical limitation on accredited investors. ${ }^{135}$ Moreover, under its expanded Section 28 authority to create registration exemptions, there is no statutory reference to "small amounts"

130. The disclosure requirements vary depending on the amount of the offering and whether the issuer is a 1934 Act reporting company. See 17 C.F.R. \$ 230.505-06 (2007).

131. 17 C.F.R. $\$ 230.502$ (b) (2) (v) (2007).

132. 17 C.F.R. $\$ 230.502$ (b) (2) (iv) (2007).

133. 17 C.F.R. $\$ 230.502$ (b) (2) (vii) (2007).

134. Securities Act of $1933 \S 3$ (b), 15 U.S.C. $\S 77$ c (2004).

135. Moreover, Section 3(b)'s language is not applicable to Rule 506, which was adopted not under Section 3(b) authority but pursuant to the Commission's general rule-making authority. 15 C.F.R. $§ 230.506$ (2007). 
or the "limited character" of the offering. ${ }^{136}$ Despite the expansion of its authority, and the continual concerns expressed by advocates of small business financing, the Commission's Rules 505 and 506 persist in prohibiting small companies from selling securities to more than 35 ordinary investors. It is time that this prohibition is examined in light of realistic investor protection goals.

\section{Integration}

The financial demands for smaller companies are often sporadic and immediate. ${ }^{137}$ For many companies in development stages, "imetables cannot accurately forecast the need to hire personnel, purchase additional equipment, invest in new research, undertake marketing initiatives, modify existing or potential products, or acquire other technologies. These needs require immediate access to investment capital. Yet, young companies usually do not have revenue or income streams sufficient to finance an expanding business. Bank loans are generally not available without substantial outside collateral, and the capital resources of the founders and initial investors are often entirely consumed through early stage development. If pressing business needs are to be met, there may be little choice but to seek funds from investors through equity or debt sales. A registered offering is not feasible, for both time and resource reasons, leaving only the option of raising capital through an exempt offering. In addition to the significant difficulties posed by the technical requirements of the various exemptions, we now add to the mix the doctrine of "integration," a doctrine of questionable justification that is entirely inimical to the capital needs of small companies.

Integration as a securities law concept has been analogized to the IRS step-transaction doctrine under which transactions that appear to be separate in form are examined as to substance to determine whether or not, in fact, they should be

136. Securities Act of $1933 \S 28,15$ U.S.C. $77 z-3$ (2000). ("The Commission, by rule or regulation, may conditionally or unconditionally exempt any person, security, or transaction, or any class or classes of persons, securities or transactions, from any provision or provisions of this subchapter or of any rule or regulation issued under this subchapter, to the extent that such exemption is necessary or appropriate in the public interest, and is consistent with the protection of investors.").

137. See discussion supra Part I. 
treated as distinct transactions. ${ }^{138}$ The integration doctrine is entirely SEC-developed and is intended to assure that there are clear delineations between the ending of one offering and the start of another so that the relevant exemption conditions can be applied. Thus, for example, suppose that an issuer undertakes a Rule 505 offering and sells $\$ 3$ million of securities to 35 non-accredited investors to finance the construction of a warehouse. One week following the sale to the 35 th non-accredited investor, the issuer announces a new issue of $\$ 3$ million of securities to be sold to another 35 non-accredited investors and the proceeds to be used to further the warehouse construction under a purported new Rule 505 offering. These are clearly evasive tactics to avoid both the numerical and monetary limitations of Rule 505. In these circumstances, the issuer cannot appropriately claim that the first Rule 505 offering ended and that the second was a distinctly new Rule 505 offering. To allow such run-on offerings would emasculate the Rule 505 conditions. The integration doctrine appropriately would treat the two offerings as unified and thus the combined offerings must fit within an exemption other than Rule 505 (which has been exceeded) or be registered.

The integration doctrine initially arose in the context of the intrastate offering exemption to explain the statutory "part of an issue" language. ${ }^{139}$ Inasmuch as the entire issue must be offered and sold only to residents of a single state, how is the "issue" defined? Would the "issue" include, for example, sales to non-residents that occurred shortly before the start of the intrastate offering? The SEC responded to these concerns by creating a five-part test to determine when apparently distinct offerings should be regarded as part of the same "issue," to wit: ${ }^{140}$

(1) Are the offerings part of a single plan of financing?

138. Thomas Lee Hazen, The Law of Securities Regulation $\$ 4.12$ (5th ed. 2005).

139. Securities Act of $1933 \S 3$ (a)(11), 15 U.S.C. $\S 77 c(a)(11)$ (2000) ("Any security which is part of an issue offered and sold only to persons resident within a single State. ...").

140. The integration doctrine was initially formulated by the SEC to define the "part of an issue" language in the section 3(a)(11) intrastate exemption. 17 Fed. Reg. 11,896 (SEC Dec. 6, 1961). The doctrine set forth in this Release has been extended to all exempt offerings through SEC rules and interpretations. 
(2) Do the offerings involve the same class of security?

(3) Are the offerings made at or about the same time?

(4) Is the same type of consideration to be received?

(5) Are the offerings made for the same general purpose?

The existence of any one of these factors, according to the SEC, may result in imposition of the integration doctrine. As a practical matter, offerings relatively close in time will usually touch upon several of the listed factors. If integration is deemed to exist between two or more offerings, the result will usually be an unmitigated, non-curable disaster. If two purportedly exempt offerings are integrated as a result of the SEC doctrine, the two offerings will be considered as one, and that one offering must meet all the conditions of a single registration exemption. It is difficult enough to meet exemption conditions when planned. The chances of backing into an exemption for two offerings that are deemed to be integrated are remote at best. The result will almost inevitably be the loss of the exemption for both offerings, as it will be only the most serendipitous of circumstances that would result in the amalgam of distinct offerings satisfying all the technical conditions of a single exemption. ${ }^{141}$

In an effort to create certainty in place of the ambiguous five-factor integration test, and provide some relief from the strictures of the integration doctrine, the Commission created a six-month safe harbor period for the Rule 147 and Regulation D exemptions. Such exempt offerings will not be integrated with offers that expired more than six months prior to or do not start earlier than six months after the conclusion of the exempt offering. ${ }^{142}$

141. Given the technical nature of every exemption, it would be a rarity that such conditions could be satisfied in the unplanned setting of integrated offerings. Suppose for example an issuer completes a $\$ 1$ million Rule 504 offering and five months later sells securities to five investors in a Section 4(2) private offering. If those offerings are integrated, the Rule 504 exemption will be lost by reason of exceeding the monetary limit, and the Section 4(2) exemption will very likely also be lost by reason of the lack of qualifications of the Rule 504 purchasers. No other exemption is likely to come to the rescue.

142. Rule 147 (b) (2), 17 C.F.R. $§ 230.147$ (b) (2) (2007); Regulation D, 17 C.F.R. 230.502(a) (2007). The SEC's August 2007 Release proposes to shorten the integration safe harbor in Regulation D from six months to 90 days. See supra discussion in text at note 85 . Special integration rules have also been created for Regulation A offerings. 17 C.F.R. $\$ 230.251$ (c) (2007). 
The integration doctrine is particularly harsh on smaller companies for several reasons:

(1) The lack of definitive integration time frames for Section 3(a) (11) and Section 4(2) offerings makes it very difficult for small companies to utilize those exemptions if additional financing is expected to be necessary in the near future.

(2) Although offerings within six months of one another are not necessarily or even presumably integrated, the SEC safe harbors create a strong implication favoring integration.

(3) The six-month safe harbors in Regulation D and Rule 147 are too long for smaller companies whose capital needs are often sporadic and immediate. ${ }^{143}$ The August 2007 SEC proposal to shorten the integration safe harbor in Regulation $\mathrm{D}$ from six months to 90 days offers some relief in this area, but even the shortened 90-day period would be too long in our judgment and fails to address the fundamental concerns raised by the integration doctrine. ${ }^{144}$

(4) Younger companies need additional capital to finance general growth and development. Although the specific economic needs may be differentiated, e.g., among research and marketing, the "single plan of financing" and "same general purpose" factors in the integration test can readily be applied to the foreseeable growth requirements of developing companies. It will therefore be very difficult for companies to avoid the integration doctrine on grounds that the offerings are in fact for distinct purposes.

One can readily find fault around the edges with the integration doctrine. A more fundamental problem arises when one examines the doctrine from the perspective of investor

No safe harbor exists for statutory exemptions under Section 4(2) or Section 3 (a) (11) of the 1933 Act. For such offerings there is no time frame that is presumptively safe from the integration doctrine.

143. The reduction of the six-month time frame has been recommended from time to time by participants at the SEC's Government-Small Business Forum. The 2001 Final Report, for example, recommended that "The SEC should reconsider the integration rules under Rule 502 to eliminate the present safe harbor time requirements and apply the five-part test only to subsequent offerings when the prior offering has not clearly terminated." Final Report of the SEC Government-Business Forum on Small Business Capital Formation (Feb. 2002), available at http://www.sec.gov/info/smallbus/ gbfor20.htm (last visited Nov. 8, 2007).

144. See supra note 94 and accompanying discussion in text. 
protection concerns. It is appropriate to ask why an offering that has fully satisfied those concerns as to one investor group should be integrated with a distinct offering that has fully satisfied investor concerns for a second investor group? Let us suppose a relatively simple integration problem. The company has engaged in a successful intrastate offering, meeting all federal and state exemption conditions. One week later the company sells securities to several out-of-state residents in a Rule 506 offering. Both offerings raise capital for general development purposes. Given the timing and purpose of the offerings, there is little doubt that integration will be applied, with the result that the unified, integrated offering will have no exemption and, thus, the "combined" offering as so defined will be in violation of registration requirements. Yet, where in this scenario has there been any deviation from investor protection interests? The purchasers in the intrastate offering have the locallybased company to look to, the company continues to meet the revenues, proceeds, and assets tests for intrastate offerings, and any disclosure requirements imposed by state law will have been satisfied. ${ }^{145}$ Indeed, the subsequent private offering may have strengthened the company's financial capacity much to the benefit of the initial investors. Similarly, the Rule 506 purchasers were accorded all the protections required by the SEC in considering their investment decision. Indeed, their decision to invest may have been based in part on the company's successful capitalization through the intrastate offering. What basis exists, other than the integration doctrine itself, to regard these two offerings as one and deny to the company the ability to engage in such offerings?

The integration doctrine appears inconsistent with the fact that the SEC has ostensibly crafted every registration exemption in accordance with the perceived demands of investor protection. If a company meets those demands as to one exempt offering, and also meets those demands in a subsequent exempt offering, however close in time or purpose, in-

145. A company planning to engage in multiple offerings over a relatively short period of time risks a disclosure problem to the extent that later offerings will affect capital structure, company operations, voting and control issues. Disclosure of such factors may be important to investors in the initial offerings. 
vestor protection concerns have been met in both offerings. ${ }^{146}$ To apply the integration doctrine simply for the purpose of integration itself has no justification. The justification has to be investor protection, the foundation principle of the securities laws. Where distinct offerings have each fully complied with the SEC requirements, application of an integration doctrine because the company "should have waited longer" is formalistic, serves no justifiable purpose, and is particularly punitive to smaller companies.

\section{Aggregation}

The aggregation concept applies to exemptions that have monetary ceilings, i.e. Rules 504 and 505, and Regulation A. ${ }^{147}$ Analogous to integration, the aggregation doctrine examines multiple offerings and can result in the voidance of an otherwise seemingly discrete and permissible exempt offering. Unlike integration, aggregation looks only at the monetary factor, and only examines prior sales of particular offerings during a 12-month period. ${ }^{148}$ Aggregation can invalidate an offering

146. The SEC has a legitimate concern that its rules not be abused by clever avoidance. That is why a company should not be allowed to create a "new" Rule 505 offering, for example, each time it meets the numerical limit of non-accredited investors. 17 C.F.R. $\$ 230.505$ (b) (2) (ii) (2007). Although investors apprised of this process may have no objections, and may be fully protected in their interests, the company is simply trying to avoid one of the principal exemption conditions. This clear evasion of a rule's conditions can be easily recognized and prevented.

147. Rule 504(b) (2): "The aggregate offering price for an offering of securities under this Rule 504 . . shall not exceed $\$ 1,000,000$, less the aggregate offering price for all securities sold within the twelve months before the start of and during the offering of securities under this Rule 504, in reliance on any exemption under section $3(\mathrm{~b})$, or in violation of section 5 (a) of the Securities Act." 17 C.F.R. \$ 230.504(b) (2) (2007). An analogous provision exists in Rule 505, except the limitation is $\$ 5$ million. 17 C.F.R. $\$ 230.505$ (b) (2) (i) (2007). Aggregation for Regulation A offerings also goes back twelve months but applies only to securities sold under a Regulation A offering. 17 C.F.R. $\$ 230.251$ (b) (2007).

148. Aggregation for Rules 504 and 505 applies only to prior sales under Section 3(b) exemptions or in violation of the 1933 Act. 17 C.F.R. $\S 230.504$ (b) (2) (2007); 17 C.F.R. $\$ 230.505$ (b) (2) (i) (2007). Thus, a Rule 505 offering will be aggregated with Rule 504, Rule 505, and Regulation A sales during the prior 12-month period, but the offering will not be aggregated with prior private offering, intrastate, or Rule 506 sales. 17 C.F.R. $\S 230.505$ (b) (2) (i) (2007). Regulation A has a somewhat different aggrega- 
even where integration might not apply. For example, the sale of $\$ 1,000,000$ of securities under Rule 504 cannot be followed eight months later by another Rule 504 offering, despite the lack of integration. ${ }^{149}$ The latter offering would be invalid, for the $\$ 1$ million aggregation maximum would have been met.

As with integration, it is fair to ask whether any investor protection goals are achieved through the aggregation doctrine. Assuming that there are no disclosure issues as to potential dilution, voting, control, or other concerns as a result of the multiple offerings, ${ }^{150}$ it is difficult to find a justification for the aggregation doctrine other than the doctrine itself. ${ }^{151}$ And once again an SEC provision falls most harshly on smaller companies, which are the ones most likely to be raising capital under one of the monetarily-limited exemptions.

The fraternal twins integration and aggregation are sound doctrines that have been expanded beyond their fundamental valid rationale. In our judgment, each should be cut back to achieve its basic purpose, the avoidance of abusive offerings by issuers clearly evasive of regulatory standards. The integration doctrine should be pruned to clearly delineate the conclusion of one offering from the beginning of another utilizing the same exemption, but it should not apply to offerings that each satisfy distinct exemption conditions. Similarly, aggregation (assuming the concept is retained) should be applied to ensure that an exemption based on a monetary ceiling is not subverted by artificial separation of one offering into two or more

tion provision which looks only to prior Regulation A sales within a 12 month period. 17 C.F.R. $\$ 230.251$ (b) (2007).

149. The six-month safe harbor of Rule 502(a) would preclude integration of these two offerings. See 17 C.F.R. $\$ 230.502$ (a) (2007).

150. It is curious to note that disclosure concerns, if they existed, would not be required to be disclosed to potential investors under Rule 504, which has no disclosure conditions. See 17 C.F.R. $\$ 230.504$ (2007). Disclosure concerns would also not be required to be disclosed to accredited investors under Rule 505, to whom no disclosure obligations are owed. See 17 C.F.R. $\S 230.505$ (2007). The lack of disclosure requirements in these circumstances belies the notion that the integration and aggregation doctrines were based on disclosure concerns.

151. The Section $3(\mathrm{~b})$ maximum of $\$ 5$ million applies to "the aggregate amount at which such issue is offered to the public." Securities Act of 1933 $\$ 3$ (b), 15 U.S.C. $\$ 77$ c (2004). This is not equivalent to the SEC's aggregation doctrine that applies to sales made under distinct offerings even if not integrated. 
tenuously distinct offerings. Each offering should stand on its own merits. If an initial offering meets all exemption conditions, a second offering meeting all exemption conditions should not be integrated or be subject to aggregation except in clear, evasive circumstances.

\section{E. Potential Loss of Exemption Through Resales}

Securities purchased pursuant to Section 4(2), Rule 506, Rule 505, and in some circumstances Rule 504, ${ }^{152}$ are "restricted securities" subject to resale limitations. ${ }^{153}$ Resale limitations are imposed in part to assure that a purchaser in an exempt offering does not become a conduit to others who would not be eligible purchasers under the exemption and in part to avoid a secondary market beginning without adequate public information. As a general rule, restricted securities cannot be resold except pursuant to Rule 144, the safe harbor adopted by the SEC to determine when restricted securities, and securities owned by control persons, may be safely resold. ${ }^{154}$ The minimum holding period of restricted securities under Rule 144 is one year. ${ }^{155}$ If any resales of "restricted securities" occur within the one-year period, or otherwise not in

152. Securities acquired in a Rule 504 offering are restricted pursuant to Rule 502(d) unless the offering was state registered or made under a state's accredited investor exemption. 17 C.F.R. $\$ 230.504$ (b) (2007).

153. Regulation D, 17 C.F.R. \$ 230.502(d) (2007) (stating “. . securities acquired in a transaction under Regulation $D$ shall have the status of securities acquired in a transaction under Section 4(2) of the Act and cannot be resold without registration under the Act or an exemption therefrom."). The term "restricted securities" is applied to such securities in Rule 144. 17 C.F.R. $\$ 230.144$ (a) (3) (ii) (2007).

154. Rule 144, 17 C.F.R. $\S 230.144$ (2007). Rule 144 is not exclusive, meaning that there may be a resale not meeting Rule 144 conditions that could also not constitute an underwriting. However, Rule 144 is the dominant set of conditions and any resales not in accordance with Rule 144 are fraught with the "underwriter" risk.

155. Rule 144(d)(1), 17 C.F.R. $\$ 230.144$ (d)(1) (2007) (“A minimum of one year must elapse between the ... date of the acquisition of the securities from the issuer . . . and any resale of such securities in reliance on this section. ..."). In December, 2007, the SEC shortened the holding period to six months for securities of 1934 Act reporting companies. Revisions to Rule 144 and 145, Securities Act Release No. 33-8869, 2007 WL 4441239 (Dec. 17, 2007). Most small companies selling securities under registration exemptions are not 1934 Act reporting companies and the minimum one-year holding period remains applicable. 
accordance with all of the Rule 144 provisions, there is a substantial danger that the seller would be regarded as an "underwriter," that is, as one who is engaged in a distribution on behalf of the issuer. Not only would the seller be at risk, but there is also a likelihood that the issuer's distribution of securities under its exemption would be regarded as continuing, and the resale would be judged against the standards of the initial exemption. This puts the issuer at enormous risk of losing its exemption ex post facto, as subsequent resales might cause the total number of purchasers to exceed the numerical limits, might be to persons who are not eligible under the exemption conditions, or might be made without the disclosure mandated by the particular exemption under which the issuer sold the securities.

Complicating the resale problem even further is the fact that privately-held companies often cannot take advantage of the resale safe harbor provided by Rule 144. Rule 144 provides that as a condition for resale there be available at the time of resale "adequate public information" with respect to the issuer of the securities. ${ }^{156}$ For publicly-held companies, this condition is met by compliance with the quarterly and annual reporting provisions of the 1934 Securities Exchange Act. For smaller companies that have not engaged in a registered offering and whose securities are not registered under the 1934 Securities Exchange Act, the public information requirement will be met only if certain specified information is provided to broker-dealers who offer quotations in securities. ${ }^{157}$ Most small businesses have no secondary market for their securities and there are no broker-dealer quotations. The result is that, with few exceptions, small, privately-held issuers have no safe harbor to counter the potentially fatal effect of one or more resales of securities issued in an otherwise exempt transaction. ${ }^{158}$

156. Rule 144(c), 17 C.F.R. $\S 230.144$ (c) (2007).

157. 17 C.F.R. $\$ 230.144$ (c) (2) (2007) ("If the issuer is not subject to section 13 or 15 (d) of the Securities Exchange Act of 1934, there is publicly available the information concerning the issuer specified in paragraphs (a) (5) (i) to (xiv), inclusive, and paragraph (a) (5) (xvi) of Rule 15c2-11 under that Act ....").

158. Insurance companies may qualify for the safe harbor by providing the information specified in Section 12(g)(2)(G)(i) of the Securities Exchange Act of 1934. Banking corporations and other regulated depository institutions are required to file monthly operational and financial reports 
Shares obtained in an intrastate offering under Section 3 (a) (11) or Rule 147 are not "restricted" in the technical sense of Rule 144, but resale limitations apply. In particular, if purchasers sell their shares to non-residents, such resales may cause the issuer to lose the intrastate exemption. The principal question is whether the securities have "come to rest" within the issuer's state prior to any out-of-state resales. ${ }^{159}$ In an effort to drive home to purchasers the importance of not making such resales, issuers will often obtain from purchasers letters of investment intent denying any plan or intention to resell the securities. These letters are of limited evidentiary value compared to the time frame that elapses between the purchase and resale. The time frame controls the "coming to rest" doctrine, yet for Section 3(a) (11) transactions there is no statutory or regulatory safe harbor or other provision determining time frame parameters. The burden of proof is on the issuer to show that all exemption conditions have been satisfied, including the burden to show that the securities came to rest within the state prior to any resales. ${ }^{160}$ Given the lack of any firm standards, the issuer's burden of proof may be difficult to sustain if out-of-state resales occur, despite the issuer's best efforts to prevent them, within a few months after the close of the issuer's offering. Although Rule 147 eliminated

with the federal bank regulatory agencies. This information is publicly available and sometimes is relied upon by attorneys giving opinions in connection with transfers of restricted securities of such financial institutions.

159. Securities Act Release No. 4,386, 1961 WL 61608 (July 12, 1961) ("the quick commencement of trading and prompt resale of portions of the issue to non-residents raises a serious question whether all of the issue has, in fact, come to rest in the hands of the investors resident in the state of the initial offering.").

160. In Busch v. Carpenter, 827 F.2d 653 (10th Cir. 1987), involving resales to non-residents seven months after a Section $3(\mathrm{a})(11)$ offering, the court held that the issuer had made out a prima facie case of compliance with Section 3(a)(11) because all initial purchasers were in-state residents, and that the burden of proof then shifted to plaintiffs to show that the securities had not come to rest within the state, a burden that plaintiffs failed to meet. This holding was contrary to the SEC's amicus brief and with the obligation of the issuer, as enunciated in $S E C v$. Ralston Purina, note 46, supra, to prove all elements of an exemption, including the "coming to rest" requirement. The court's willingness to regard a seven-month time frame as sufficient for Section 3(a)(11) purposes may be of comfort to those looking for standards, but the court's approach to the burden of proof issue renders the decision suspect as to precedential value. 
the uncertain time frame by adopting a nine-month period from the date of issuer's last sale, ${ }^{161}$ the fundamental problem remains that an issuer that otherwise meets all of the intrastate exemption conditions could lose the exemption by reason of a purchaser's all-too-soon out-of-state gift or resale of the securities. ${ }^{162}$

The SEC is well aware of the resale problem posed to issuers and has provided in Regulation D, and in Rule 147, a list of measures that an issuer can take to attempt to protect itself. These measures include restrictive legends on certificates, stop transfer instructions to transfer agents or company registrars, and written disclosure of resale limitations. ${ }^{163}$ However, conformity to the SEC guidelines does not immunize the issuer from resale problems. Although the precautionary measures to be taken by issuers are mandatory in Rule 147 , there is no provision protecting issuers that adopt such measures. Similarly, the measures set forth in Regulation D are simply examples of "reasonable care" that an issuer should take to assure that purchasers do not become underwriters. ${ }^{164}$ There is no provision protecting issuers that have taken such measures but find that resales have been made despite their efforts.

Resale limitations are appropriate to assure the integrity of an exemption where numerical, disclosure, or purchaser qualification conditions exist. Although resale limitations can chill a potential investor's desire to purchase securities, or re-

161. 17 C.F.R. $\$ 230.147$ (e) (2007). The nine month period does not begin to run until the issuer's final sale under Rule 147, and thus for any particular purchaser the time frame can be quite a bit longer and, without precise knowledge of issuer's activities, quite uncertain. The uncertainty could readily lead to good faith yet mistaken beliefs that the nine month period has expired.

162. See, e.g., Williamsburg Apartments, SEC No-Action Letter, 1974 WL 10014 (Jan. 10, 1974) (SEC staff refused to give no-action letter regarding a proposed gift of small number of shares to non-resident).

163. Compare 17 C.F.R. $\$ 230.147$ (f) (2007), with 17 C.F.R. $\$ 230.502(d)$ (2007). The list of measures are not identical. Rule 502(d) makes no reference to stop transfer instructions but includes a "reasonable inquiry" that the purchaser is acquiring the securities for himself or another person.

164. 17 C.F.R. \$ 240.502(d) (2007). Rule 502(d), 17 CFR 240.502(d) (2007) ("The issuer shall exercise reasonable care to assure that the purchasers of the securities are not underwriters within the meaning of section 2(11) of the Act, which reasonable care may be demonstrated by the following ...."). 
sult in undervaluation of the offered security, the limitations are an appropriate safeguard against abuse of the exemption conditions. However, where the issuer has taken reasonable steps in good faith to prevent improper resales, the exemption from registration should not be lost by reason of unforeseeable, improper transactions beyond the issuer's control. Whatever damage a resale causes to the integrity of the initial exemption is not sufficient, in our judgment, to impose upon a good faith issuer the risk of an offering violation. ${ }^{165}$

\section{F. Lack of Coordination with State Law}

No federal exemption from registration other than Rule 506 exempts the issuer from state registration requirements. ${ }^{166}$ The substantial problems caused by the lack of federal-state uniformity, and the disparate laws at state levels, were noted by Congress over 25 years ago when it added Section 19 (c) to the 1933 Securities Act, authorizing the Commission to cooperate with state securities administrators "in effectuating greater uniformity in Federal-State securities matters."167 Among the cited purposes for such uniformity was "minimum interference with business of capital formation." 168

Spurred by Congressional mandate, the SEC and the North American Securities Administrators Association (NASAA) sat down to create a state exemption that would be coordinated with at least one major federal exemption. The result was the Uniform Limited Offering Exemption ("ULOE") adopted by NASAA in 1983 and subsequently

165. The statute of limitations for violation of the registration requirement is one year. Securities Act of 1933, $\$ 13,15$ U.S.C. $77 \mathrm{~m}$ (2005). If a violation occurs within that period and, as a result, the issuer loses its claimed exemption, the draconian result is that the entire offering is subject to rescission rights by purchasers along with interest. Securities Act of 1933 $\S 12$ (a) (1), 15 U.S.C. $\$ 771$ (a) (1) (2005).

166. Rule 506 offerings come under the concept of "covered securities" that are exempt from state registration requirements. National Securities Marketing Improvement Act of 1996, Pub. L. No. 104-290, 110 Stat. 3416 (1996).

167. The provision has since been moved to subsection $19(d)(1)$. Securities Act of $1933 \S 19(\mathrm{~d})(1), 15$ U.S.C. $\$ 77 \mathrm{~s}(\mathrm{~d})(1)(2005)$.

168. The provision has since been moved to subsection $19(\mathrm{~d})(2)(\mathrm{C})$. Securities Act of $1933 \S 19(d)(2)(C), 15$ U.S.C. $\$ 77 s(d)(2)(C)(2005)$. 
adopted by most states. ${ }^{169}$ ULOE was modeled after the thenrecently adopted Rule 505 of Regulation D. However, ULOE contains significant requirements beyond those found in Regulation D. Foremost among the additional limitations are suitability standards that prohibit sales to non-accredited investors unless the issuer has reasonable grounds to believe that the investment is suitable based on the investor's financial situation and needs or that the purchaser, either alone or with a purchaser's representative, has knowledge and experience to evaluate the investment's merits and risks. These requirements go far beyond Rule 505, which has no financial or sophistication requirements applicable to non-accredited investors. ${ }^{170}$ If the Congressional purpose in mandating a cooperative effort was to create uniformity between federal and state exemptions, ULOE did not meet that purpose.

A more profound problem with ULOE is that its basis is Rule 505, an exemption laden with the Regulation D prohibitions against general solicitation and advertising, an impractical ceiling on the number of non-accredited purchasers, a monetary ceiling that in today's economy is unrealistically low, and the twin doctrines of integration and aggregation. Rule 505 is one of the least useful federal exemptions, and ULOE burdens companies even more with additional conditions that limit a company's efforts to market its securities. In short, ULOE fails to achieve the Congressional purpose of "minimum interference" with capital formation.

The goal of coordinated federal-state registration exemptions will not be achieved as long as states continue to apply registration and exemption provisions without regard to federal exemptions. Although some states have adopted exemptions that tie into the federal scheme, these instances are the

169. ULOE has been adopted in approximately 40 states. Some states that have not adopted ULOE nevertheless have state exemptions that fairly analogous to the Rule 505 conditions, such as numerical limits, no general advertising or solicitation, and disclosure requirements.

170. The current ULOE form may be found in NASAA Reports (CCH). Other ULOE conditions not found in Rule 505 are a limitation on payment of commissions only to state-licensed dealers and state-oriented worthy issuer provisions. 
exception. ${ }^{171}$ The principal state exemption other than ULOE in most states is one based on a very limited number of purchasers in a 12-month period and the absence of general advertising and solicitation. ${ }^{172}$ Even if a company is able to wend its way through the technicalities of a federal exemption, state laws will often impede an effective marketing effort. ${ }^{173}$

We do not advocate elimination or complete preemption of state securities laws. State registration and exemption provisions should continue to be applied to intrastate offerings under Section 3(a) (11) or Rule 147, as those exemptions are based on the ability of states to regulate such local offerings. State enforcement of antifraud provisions is also an important tool for investor protection and no federal preemption should apply to state enforcement measures. However, beyond these parameters, we believe that serious consideration should be given to a broader preemption approach to clear the cluttered decks of overlapping and inconsistent federal-state registration exemptions.

Federal legislation providing for preemption of state registration laws beyond the current status is likely to be met with substantial state opposition. ${ }^{174}$ State administrators are

171. For example, New Jersey, Colorado, and Oklahoma are among a handful of states that treat a Regulation A offering as exempt from state registration.

172. UNIF. SEC. ACT $\S 402$ (b) (9) (1956) (transaction directed to not more than 10 persons in the state in a 12 -month period if seller reasonably believes that all buyers are purchasing for investment and no commissions paid to any person); $\S 402(11$ ) (no more than 25 purchasers in state in 12-month period, no general solicitation or general advertising, no commission other than to licensed broker-dealer unless exemption, and either (i) seller reasonably believes all purchasers are purchasing for investment or (ii) immediately after sales, securities of issuer held by 50 or fewer persons and aggregate offering does not exceed $\$ 500,000)$. Many states have adopted either the 1956 or 1985 versions of the Uniform Securities Act, with substantial variations being made to its provisions including transactions exempt from registration.

173. An additional problem with ULOE is the lack of uniform adoption among states. ULOE has not been adopted by every state. A number of states that have adopted ULOE have modified or added to its requirements. The result is a continuing hodgepodge of state exemptions, causing small companies and their counsel to continue to have to examine and react to differing state laws.

174. In January, 2008, the North American Securities Administrators Association announced its legislative priorities for 2008 , chief among them being 
wary about ceding any autonomy over securities offerings, for securities frauds that occur from time to time have enormous local impact and inevitably lead to fingers pointed at state regulatory agencies. Washington is distant and faceless. State administrators often bear the brunt of criticism when defrauded investors discover their losses. State administrators are likely to view with alarm efforts to increase the opportunities for unregistered offerings and the preemption of state registration and exemption requirements. Nevertheless, the status quo is equally inimical to the universally acknowledged desire to facilitate capital raising opportunities for legitimate small businesses. Rather than simply declare an irresolvable impasse, new efforts should be undertaken to consider a carefully constructed coordinated exemption scheme that fosters the goals of capital growth and investor protection. Federal preemption may be a necessary element but it must be examined consistent with state concerns for the welfare of its citizens.

\section{G. Unregistered Brokers and Exempt Offerings}

Under the Blue Sky laws of many states, payment of commissions or other compensation to securities intermediaries is limited to persons who are registered in those states. ${ }^{175}$ Therefore, sales payments to an unregistered person could jeopardize the issuer's exemption from registration. A "broker" is a person "engaged in the business of effecting transactions in securities for the account of others." 176 Smaller transactions are not generally attractive to most securities broker-dealers for economic and potential liability reasons. Nevertheless, there are literally thousands of "finders" and other persons willing to match private investors and smaller companies for a fee, typically contingent on a percentage of the funds contributed. Most of these persons are not registered as broker-dealers with the Financial Institutions National Regulatory Author-

preserving the authority of state regulators and evaluating the "negative effects" of preempting state laws. State Securities Regulators Want Congress to Ensure Their Authority, 40 Sec. Reg. L. Rep. (BNA) 161 (Feb. 5, 2008).

175. Unif. LTD. OfFERING EXemption II 6201: "No commission, fee or other remuneration shall be paid or given, directly or indirectly, to any person for soliciting any prospective purchasers in this state unless such person is appropriately registered in this state."

176. Securities Exchange Act of $1934 \S 3(\mathrm{a})(4)(A), 15$ U.S.C. $\$ 78 \mathrm{c}$ (2000). 
ity (FINRA), formerly the National Association of Securities Dealers (NASD) or the states in which they operate. Through mutual ignorance or otherwise, payment of fees to an unregistered finder can eliminate the availability of an exemption from registration.

The idea of limited registration of persons whose sole activity as a broker is in connection with private capital raising, merger and similar transactions has been endorsed in many quarters. It was the top recommendation of the SEC Government-Business Forum on Small Business Capital Formation in 2004 and $2005^{177}$ and the topic of a special workshop at the 2006 Forum. A primary recommendation of the United States Securities and Exchange Commission Advisory Committee on Smaller Public Companies in April 2006 was that the SEC spearhead a multi-agency effort to create a streamlined registration process for finders, mergers and acquisitions advisors and institutional private placement brokers ("PPBs"). ${ }^{178}$ The recommendation recognized that a critical impediment to small business capital formation could be eliminated without loss of investor protection. A large number of PPBs currently operate in a massive "gray market." The goal is to bring them into the mainstream by imposing only rational, necessary regulation on their activities. Investors will then be able to be able to access information about them, and the anti-fraud rules of the SEC and state regulatory agencies will be fully applicable to their activities. ${ }^{179}$

177. Final Report of the 24th Annual SEC Government-Business Forum on Small Business Capital Formation, Securities Regulation Recommendation \#17, available at http://www.sec.gov/info/smallbus/gbfor24.pdf (last visited Nov. 4, 2007); Final Report of the 23rd Annual SEC GovernmentBusiness Forum on Small Business Capital Formation, Securities Regulation Recommendation \#5, available at http://www.sec.gov/info/smallbus/gbfor 23.pdf (last visited Nov. 4, 2007).

178. Final Report of the Advisory Committee on Smaller Public Companies to the United States Securities and Exchange Commission, Recommendation IV.P.6, available at www.sec.gov/info/smallbus/acspc/acspc-finalreport.pdf (last visited Nov. 4, 2007).

179. The most comprehensive analysis of private transaction intermediaries is contained in the 2005 Report and Recommendation of the Task Force on Private Placement Broker-Dealers (the "Report"). The Task Force on Private Placement Broker-Dealers, Report and Recommendation of the Task Force on Private Placement Broker-Dealers 60 Bus. Law. 959 (May 2005). The Report was the culmination of more than eight years of work by the Private Placement Broker-Dealer Task Force, a group of lawyers drawn from interested 
The SEC is the logical agency to spearhead a rational regulatory reform to legitimize PPBs. FINRA is unlikely on its own initiative to take the lead role in implementing a registration procedure for PPBs. ${ }^{180}$ While several states are evaluating possible legislative and regulatory initiatives addressing some of the issues included in the Report, state action may take years to implement and would be less efficient and less effective than if the SEC takes action to coordinate the effort and encourage consistency. In fact, although states such as California, Michigan, Minnesota, Iowa, South Dakota and Texas have adopted or proposed regulations regarding finders, the provisions are not uniform and, therefore, of only limited utility. More significantly, no state regulation, however liberal, can operate on a national basis or even beyond its borders without complementary federal relief. By taking the leadership role, we believe the SEC can explore with the FINRA and the states not only the limited registration and ongoing regulatory process recommended in the Report but also alternative regimes to accomplish the same goals. For example, an exemption from federal broker-dealer registration might be appropriate if there is registration in at least one state, by analogy to the structure utilized for offerings under Rule 504 of Regulation D. Other models, such as the federal-state division of responsibility for investment advisors, might similarly accommodate the needs of the SEC, the FINRA, and the states.

\section{IV.}

Part IV: Meanwhile, Back at the Ranch: The SEC's Enigmatic SiLence

The barriers to capital-raising imposed on small companies are not unknown to the SEC. On the contrary, there has been a steady drumbeat of criticism and proposed reform measures. The mystery is why the SEC has been so reticent to

committees of the Business Law Section of the American Bar Association. The thrust of the Report's recommendations is to provide a simplified registration process and on-going regulatory oversight better adapted to the limited nature of the business of PPBs.

180. The FINRA's organization and member fee structure reflects the tremendous amount of infrastructure necessary for it properly to carry out its regulatory duties. While we believe that the limited class of PPBs easily can be fit within the self-regulatory framework, to conclude that the FINRA will do so voluntarily without direction from the Commission is, we think, naive. 
respond. Until August 2007, it had been 25 years since the last major SEC development of registration exemptions, ${ }^{181}$ and the August 2007 proposals can scarcely be called major revisions.

Despite the SEC profession of interest in small business, there has been a great deal more smoke than fire. A poignant example of this duality is the Concept Release issued in $1996,{ }^{182}$ in which the Commission sought input on a wide range of registration and disclosure issues, including the following:

Comment also is requested with regard to a broader relaxation of general solicitation prohibitions on offerings made under Regulation D Rules 505 and 506. Is the inability to reach out broadly to find qualified investors for such Regulation D offerings unnecessarily hampering the utility of the Regulation and raising costs to issuers?

Did the Commission need to ask this question? More importantly, did it listen to the answers? Every year for 10 years following the SEC request for comments, Reports from the annual SEC Government-Business Forum on Small Business Capital Formation ${ }^{183}$ contained an unequivocal recommendation that the general solicitation prohibitions be eliminated or substantially modified. ${ }^{184}$ For example, the 1996 Report, issued soon after the SEC's call for comments, stated that " $[t]$ he Commission should eliminate the general solicitation requirement for all Regulation D offerings." 185 Over ten years of constant recommendations from small business representatives

181. Regulation D was adopted in 1982. Securities Act Release No. 6,389, 1982 WL 35662 (Mar. 8, 1982); Revision of Certain Exemptions from Registration for Transactions Involving Limited Offers and Sales, 17 C.F.R. $\S 230.501-506$ (1982).

182. Effect of the 1933 Act Concepts on Capital Formation, Securities Act Release No. 7,314, Exchange Act Release No. 37,480, [1996-1997 Transfer Binder], Fed. Sec. L. Rep. (CCH) If 85, 823, at 88,291 (July 25, 1996).

183. The annual meeting is mandated by the Omnibus Small Business Capital Formation Act of 1980. See supra note 1, discussing 15 U.S.C. $\S 80 \mathrm{c}-1$.

184. Annual Reports from the Forums are available on the SEC's website at http://www.sec.gov/info/smallbus/sbforumreps.htm.

185. Final Report of the SEC Government-Business Forum on Smail Business Capital Formation, http://www.sec.gov/info/smallbus/finrep15.htm (last visited Nov. 4 2007). 
should have been sufficient answer to the Commission's 1996 inquiry. The SEC duly prepared and published the annual reports containing these and other recommendations ${ }^{186}$ and until August 2007 that was the end of the road. ${ }^{187}$

The Commission's deaf ear to Annual Forum recommendations seemed to be turned as well towards its own Advisory Committee on Smaller Public Companies. ${ }^{188}$ The Committee was formed in 2004 principally to examine the impact of the Sarbanes-Oxley Act on smaller public companies, but the Committee's charter included examination of "offering exemptions" for small businesses. ${ }^{189}$ Among the numerous findings and recommendations contained in the Committee's Final Report was Recommendation IV.P.5, calling for the adoption of a new private offering exemption "that does not prohibit general solicitation and advertising for transactions with purchasers who do not need all the protections of the Securities Act's registration requirements." 190 Echoing years of critique, the Committee Report pointed out the lack of bright-line tests, the difficulties in making judgments regarding the general solicitation standards, and the need to mod-

186. In addition to the recommendations regarding general advertising and solicitation, among the most frequent recommendations are the raising of the monetary limits on Rule 504 and Regulation A offerings, reducing the six-month integration guidelines, and seeking further federal preemption of state law for federally exempt offerings.

187. The 1996 Concept Release apparently led to the 1998 Release on Regulation of Securities Offerings. Securities Act Release No. 7,606A (Nov. 13,1998 ). The so-called Aircraft Carrier release (so-called because of the size of the release) contained numerous proposals, none of which related to the general advertising and solicitation limitations imposed on small businesses or any other exemption provisions.

188. Advisory Committee on Smaller Public Companies, Securities Act Release No. 8,514, Exchange Act Release No. 50,864, 84 SEC Docket (CCH) 1340 , at 1340 (Dec. 16, 2004) ("The Chairman of the Securities and Exchange Commission ("Commission"), with the concurrence of the other Commissioners, intends to establish the Securities and Exchange Commission Advisory Committee on Smaller Public Companies to assist the Commission in evaluating the current securities regulatory system relating to disclosure, financial reporting, internal controls, and offering exemptions for smaller public companies. ..") (emphasis added).

189. Id.

190. Final Report of the Advisory Committee on Smaller Public Companies to the United Sstates Securities and Exchange Commission at 74 (Apr. 23, 2006), available at http://www.sec.gov/info/smallbus/acspc/acspc-final report.pdf. 
ernize rules to take advantage of new communication technologies. ${ }^{191}$

It took the Commission more than a year to respond to the Advisory Committee's endorsement of the recommendations that had been made repeatedly by annual SEC-Small Business Forums. Although the August 2007 Release, including proposed Rule 507, purports to address the recommendations of the Advisory Committee, the proposals are very limited in scope and fail to remedy the concern expressed by the Advisory Committee that the current ban on general solicitation and advertising "is a significant impediment to the efficient formation of capital for smaller companies."192

We may be encouraged that the Commission is at last focusing attention on small business financing, but the wonder is that it took the Commission so long. Over the past decade, scores of new and revised rules have been proposed, debated, and issued by the SEC in numerous areas involving a vast array of regulation. ${ }^{193}$ No doubt every rule change has been prompted by an important concern. But one finds it difficult to understand from a policy standpoint why the Commission has spent countless hours and energy on numerous matters of large and small import, while scant attention has been given to the pressing capital formation problems of small businesses. While small business concerns languished, the SEC conscientiously studied and responded to various technical issues applicable to mega-companies and other larger publicly-held businesses. The mammoth Securities Offering Reform Release is-

191. "Beyond the difficulty of determining if particular contact is impermissible, however, the current ban on general solicitation and advertising effectively prohibits issuers from taking advantage of the tremendous efficiencies and reach of the Internet to communicate with potential investors who do not need all the protections of the Securities Act's registration requirements. In our view, this is a significant impediment to the efficient formation of capital for smaller companies, one that could easily be corrected by modernizing the existing prohibitions on advertising and general solicitation." Id. at 75 . (emphasis added).

192. Id.

193. For example, in recent years there have been 22 releases regarding EDGAR filings, 14 delegations of authority to the staff divisions by the Commission, and a dozen (and continuing) rules, revisions and releases regarding Sarbanes-Oxley certifications and reports. See SEC Final Rules, available at http://www.sec.gov/rules/final.shtml (last visited Nov. 3, 2007). 
sued in $2005^{194}$ contained numerous provisions easing communication rules for publicly-held companies, including such matters as forward-looking information, free-writing prospectuses, road shows, web sites, media publications, and research reports. The larger the company, the less the conditions. ${ }^{195}$ The Release was well constructed, carefully crafted, and obviously the result of long hours of research and analysis by SEC staff members. However laudable the results, one might be excused for thinking that the Release was another instance of "the rich got richer," with little benefit to companies not in the public markets. ${ }^{196}$ It remains to be seen whether the Commission's August 2007 Release marks the beginning of a more comprehensive examination of small business concerns.

\section{A. Seeking Justification for the Commission's Inaction}

In the absence of any SEC studies or findings justifying the continuing restraints on small business financing, one can only speculate as to the reasons for the Commission's lessthan-benign neglect. The following possible explanations come to mind:

194. See Securities Offering Reform, Securities Act Release No. 8,591, Exchange Act Release No 52,056, 2005 WL 1692642 (Aug. 3, 2005).

195. The Release divided companies into four categories: well-known seasoned issuers (WKSI), seasoned issuers, unseasoned issuers, and non-reporting issuers. Rule provisions varied depending on the category of issuer. Id. at 2881-88.

196. The genesis for much of the changes contained in the Release was the equally massive so-called "Aircraft Carrier" set of proposals issued by the Commission in 1998. See Securities Act Release No. 7,606A (Nov. 13, 1998). The 2005 Release contained two provisions that could be helpful to first-time issuers in an IPO. One provision allows such issuers to use "free writing prospectuses" after the filing of a registration statement, pursuant to newly created Rules 164 and 433.17 C.F.R. $\$ \$ 230.164,433$ (2007). A second provision creates a safe harbor against "gun-jumping" concerns for communications by issuers more than 30 days prior to filing a registration statement, as long as there is no reference to a securities offering. 17 C.F.R. $\S 230.163 \mathrm{~A}$ (2007). 


\section{The Commission May Believe that Current Regulations are Adequate to Address the Capital Formation Problems of Small Businesses}

Does the Commission regard the current set of registration exemptions sufficient for small business financing? This scenario seems unlikely. It is clear, for example, that Section 3 (b)'s $\$ 5$ million ceiling established over 25 years ago is woefully inadequate in today's economy, to say nothing of the $\$ 1$ million ceiling imposed on Rule 504. Did the Commission receive no message from Congress' adoption in 1996 of Section 28 to the 1933 Act authorizing the Commission to create registration exemptions without monetary limits? 197 It must also be plain to the Commission that its attempt in Regulation A to ameliorate timing and cost problems through a "test the waters" concept has been thwarted by the refusal of most states to allow pre-filing solicitation without state registration. Moreover, the Commission cannot be impervious to the constant stream of recommendations from the Small Business Forum to eliminate or modify the prohibitions against general advertising and solicitation or the recent conclusion of its own Advisory Committee on Smaller Public Companies that the current anti-solicitation rules were "a significant impediment to the formation of capital for smaller companies." 198

In 1978, the Commission initiated public hearings to discuss small business financing, noting in the call for study that "Some have contended further that the net effect of these [SEC] policies is to endanger the continued existence of smaller companies and to inhibit the formation of new enterprises." 199

197. "The Commission, by rule or regulation, may conditionally or unconditionally exempt any person, security or transaction, or any class or classes of persons, securities, or transactions, from any provision or provisions of this title or of any rule or regulation issued under this title, to the extent that such exemption is necessary or appropriate in the public interest, and is consistent with the protection of investors." Securities Act of $1933 \S 28,15$ U.S.C. $\S 77 \mathrm{z}-3$ (2004).

198. See supra note 190 , at 75 .

199. Examination of the Effects of Rules and Regulations on the Ability of Small Business to Raise Capital and the Impact on Small Business of Disclosure Requirements Under the Securities Act, Securities Act Release No. 5,914, Exchange Act Release No. 14,529, 14 SEC Docket 314, at 316 (Mar. 6, 1978). 
The 1978 Study led to the adoption of Regulation D in 1982. Although Regulation D replaced and modified prior existing exemptions under Rules 146, 240 and 242,200 the revised exemptions did not significantly reduce the compliance problems for small businesses. Nevertheless, the SEC soon found reason to congratulate itself for a job well done. An SEC Study of Regulation D, issued in 1984 two years after the Regulation's promulgation, ${ }^{201}$ examined the 7,222 Regulation D filings that had been made from April 1982 through 1983, totaling $\$ 15.5$ billion of intended sales. The Study found the sales figures to be "impressive, and much of the credit for the large amount of intended sales must be given to the simplification of the exemptive offering process." 202

Let's examine the "impressive" Regulation D filing figures. The figures indicate 4,130 filings on an annualized basis. ${ }^{203}$ In 1984, there were a reported 4,815,000 non-farm companies other than sole proprietorships. ${ }^{204}$ The Regulation D filings therefore represented less than $1 / 10$ th of $1 \%$ of all nonfarm enterprises. How did the other $99.9 \%$ of all companies raise capital? Perhaps some used unreported exemptions, such as Section 4(2) and the intrastate offering exemptions. Those numbers cannot be too significant. For many smaller companies, Regulation D's Rule 506 has material advantages over Section 4(2), such as its focus on purchasers rather than offerees, its acceptance of purchaser representatives, and its elimi-

"The Commission, by rule or regulation, may conditionally or unconditionally exempt any person, security or transaction, or any class or classes of persons, securities, or transactions, from any provision or provisions of this title or of any rule or regulation issued under this title, to the extent that such exemption is necessary or appropriate in the public interest, and is consistent with the protection of investors." Securities Act of $1933 \S 28,15$ U.S.C. $\$ 77 z-3$ (2004).

200. See supra notes $80-81$ and accompanying text.

201. An Analysis of Regulation D [1984 Transfer Binder] Fed. Sec. L. Rep. (CCH) I 83,631 (May, 1984).

202. Id.

203. The 1983-4 figures are offered for purposes of analysis only and can be deemed only illustrative since the Commission no longer issues figures regarding total number of annual Regulation D filings.

204. 2007 Table 724, Number of Returns, Receipts, and Net Income by Type of Business: 1980 to 2003, U.S. Census Bureau, the 2007 Statistical Abstract: the National data Book, Statistical Abstract of the U.S. 487, available at http://www.census.gov/compendia/statab/tables/07s0724.xisprod/2006 pubs/07statab/business.pdf 
nation of disclosure requirement to accredited investors. Small companies are, therefore, much more likely to avail themselves of Rule 506, which would be included in the reported 1983-4 figures. Intrastate offerings are not federally reported, but they will often be subject to state registration if they do not meet the rather narrow state exemptions. State registration figures for companies utilizing federal exemptions have never been large, principally because companies that need to register at the state level find there to be little advantage to avoidance of federal registration. ${ }^{205}$ Rounding out the figures would be the Regulation A filings. Problems with that exemption have resulted in its relative non-use. In 2002, there were only 30 Regulation A filings. ${ }^{206}$

While impossible to know the total number of exempt offerings made on an annual basis, the SEC's reported figures suggest that the numbers are relatively small. Let us err on the generous side and assume twice as many exempt offerings as the reported number of 1983-4 Regulation D filings. That results in approximately 12,400 annual offerings pursuant to statutory and regulatory exemptions, a not-so-whopping $2.5 \%$ of all companies as of 1984 , and less than $2 \%$ of all companies using more recent figures. ${ }^{207}$ It is difficult if not impossible to believe that on an annual basis $98 \%$ of all non-farm companies do not raise capital from investors through the sale of equity or debt securities. ${ }^{208}$ It is much easier to believe, especially

205. For example, the Ohio Division of Securities reported that in 2006 there were 152 offerings registered in Ohio, compared to nearly 2,000 exempt offerings that were filed with the state. Of the 152 registered offerings, it may be reasonably assumed that the majority were federally registered offerings that were registered by coordination in Ohio, rather than offerings registered by qualification such as intrastate offerings. 4 Онго DEP'т ОF СомMerce, Drv. OF Sec. OHIO SEC. Q.Bull. at 13 (2006), available at http://www. securities.state.oh.us/bulletin/documents/BUL064.pdf.

206. 2002 SEC ANN. REP. at 79, available at http://sec.gov/pdf/annrep02/ ar02full.pdf. The SEC subsequently stopped reporting Regulation A filings as a separate figure.

207. See supra note 204, at 487 (indicating total non-farm business enterprises other than sole proprietorships at 7.77 million in 2003).

208. Of course these are rough figures at best. The total number of companies is based on tax returns, which may not reflect all business enterprises. The size of such companies is not well known, but studies indicate that over $98 \%$ of all enterprises have less than 100 employees. BizStats.com, Free Business Statistics and Financial Ratios, http://www.bizstats.com/reports/industry-sales-firm-summary.asp (last visited March 1, 2007) (providing yearly total 
based on the constant pleas for reform, that a significant number of companies are forced to raise capital in ways that do not conform to statutory and regulatory exemptions, hoping to avoid the SEC's radar and potential civil liabilities.

\section{The Commission May Be Concerned That Modifications to Existing Limitations Would Undermine Investor Protection}

Is the Commission fearful that reducing constraints on small business financing would open the door to abusive offerings? Investo: protection is the catalyst and continuing principal policy concern of the securities laws, a concern that cannot be discounted or subordinated to capital raising goals. There is just cause for concern regarding abusive offerings, a concern that militates against the easing of exemption conditions. The Commission could point to its recent experience with Rule 504. In 1992, the SEC eliminated from Rule 504 both the anti-solicitation provisions of Rule 502(c) and the resale limitation provisions of Rule 502(d). These amendments basically made Rule 504 a condition-free exemption except for the monetary ceiling and integration limitations. In 1999, the SEC recanted, reinstating both the Rule 502(c) and Rule 502(d) limitations for Rule 504 offerings that were not state registered (with a disclosure document) or were not made under a state exemption that permits offers and sales only to accredited investors. ${ }^{209}$ The SEC's about-face was the product of its concern over so-called "pump and dump" schemes centered in the state of New York, which, unlike most other states, has no registration requirement applicable to Rule 504 offerings. Rule 504 was being used by nefarious promoters to distribute up to $\$ 1$ million of securities in New York to a select favored group, followed promptly by boiler-room promotions that artificially drove up the secondary market price until such time as the initial purchasers could sell their shares at a handsome profit,

number of U.S. businesses). Finally, an unknown portion of the Regulation D filings reported in the 1984 SEC Study were not by small companies but by venture capital companies and large corporations utilizing Rule 506 for capital raising purposes.

209. Revision of Rule 504 of Regulation D, the "Seed Capital Exemption," Securities Act Release No. 7,644, 69 SEC Docket 364, 368 (Feb. 25, 1999). 
leaving the gullible crop of new investors with suddenly deflated shares and irrecoverable losses. ${ }^{210}$

No one would argue that the SEC should undermine investor protection in favor of liberalizing the capital formation opportunities of small companies. But examination of the securities violations that are of principal concern reveals that no amount of technical exemption requirements will hinder the fraud artists from their endeavors. As the Supreme Court noted over 60 years ago, there are "countless and variable schemes devised by those who seek the use of the money of others on the promise of profits." ${ }^{211}$ Fraudulent and deceptive schemes have unfortunately continued unabated and independent of formal registration or exemption requirements. ${ }^{212} \mathrm{De}-$ liberate securities scams are not registered, as they would be quickly discovered through review of disclosure documents. To the extent that illegitimate schemes seek to rely on registration exemptions, inevitably those offerings are replete with material misrepresentations and omissions. The disclosure

210. Unfortunately, there have been recent disturbing developments in the secondary markets for some securities initially issued under Rule 504, and to a lesser degree, in the initial Rule 504 issuances themselves. These offerings generally involved the securities of "micro cap" companies, i.e., those characterized by thin capitalization, low share prices, limited public information and little or no analyst coverage. Recent market innovations and technological changes, most notably, the Internet, have created the possibility of nation-wide Rule 504 offerings for securities of non-reporting companies that were once thought to be sold locally. In some cases, Rule 504 has been used in fraudulent schemes to make prearranged "sales" of securities under the rule to nominees in states that do not have registration or prospectus delivery requirements. As a part of this arrangement, these securities are then placed with broker-dealers who use cold-calling techniques to sell the securities at ever-increasing prices to unknowing investors. When their inventory of shares is exhausted, these firms permit the artificial market demand created to collapse, and investors lose much, if not all, of their investment. This scheme is sometimes colloquially referred to as "pump and dump." Id. at 365-66.

211. SEC v. W.J. Howey Co., 328 U.S. 293, 299 (1946) (involving the definition of "investment contract" as applied to the sale of orange groves with optional servicing contracts).

212. See, e.g., SEC v. Edwards, 540 U.S. 389 (2004) (holding that the sale and leaseback of pay telephones to hundreds of investors constitutes a securities offering); Kathy Chu, Scam Artists Target Seniors' Savings, USA Today, June 27,2007 , at $4 \mathrm{~B}$ (reporting that $46.2 \%$ of investor complaints by senior citizens to state administrators in 2004/2005 involved the sale of unregistered securities). 
problems alone give rise to civil and criminal actions and rescission rights. ${ }^{213}$ As discussed in Part $\mathrm{V}$, we strongly urge the SEC to incorporate a disclosure requirement for all federal exemptions and for all purchasers, regardless of accredited investor status. It is not the legitimate small businesses that are creating the enforcement headaches for SEC and state regulators. If many of the technical requirements of registration exemptions were eliminated and replaced by a full disclosure obligation, legitimate small businesses would have much greater access to capital markets without opening the door to nefarious investment schemes.

Perhaps the SEC is concerned that private placements of securities are more "dangerous" for investors than registered offerings because of the lack of gatekeeper oversight. It certainly is true that a registered offering brings together an array of professional advisors and intermediaries to assist the issuer. Lawyers and accountants and, of course, underwriters help ensure that regulatory requirements are complied with and the disclosure prospectus is complete and accurate. The rigorous review and participation by experienced and knowledgeable advisors - and the potential liability to which underwriters are exposed - clearly increase investor protection. However, as discussed at the outset of this article, smaller offerings cannot support the professional fees and brokerage commissions of a public offering, and smaller offerings simply do not attract the attention and interest of the broker-dealer community. Imposing the registered public offering conduit apparatus on an exempt offering is impossible as a practical matter, and we be-

213. Non-accredited investors are entitled to full disclosure for Rule 505 and 506 offerings, and all offerees are entitled to full disclosure under Regulation A. Rule 504 offerings are invariably registered at the state level to take advantage of the marketing and free transferability elements of that exemption. Although the intrastate exemptions do not have a disclosure condition, any kind of general offering is likely to be subject to state registration and concomitant disclosure requirements. The Section 4(2) private offering demands access to or full disclosure of material information to all offerees and purchasers. Thus, none of these exemptions are likely to be followed by promoters of deliberately fraudulent schemes. That leaves only accredited investors in Rule $\mathbf{5 0 5}$ and 506 offerings as an unprotected class regarding disclosure. In the authors' opinion, this is an unfortunate situation which should be remedied. In any event, one would hope that accredited investors are capable of discerning unwise investment opportunities, and if not, that Rule $10 \mathrm{~b}-5$ and state law remedies might offer them some relief. 
lieve it is unnecessary. The primary purpose of the participating professionals in the public offering process is to ensure that investors get the whole story, risks as well as opportunities, of the investment. We believe an exemption program that emphasizes full disclosure achieves that purpose. State and federal anti-fraud rules, vigorously enforced through civil, criminal and administrative remedies, along with robust requirements on broker quotations and trading, should provide sufficient protection to permit greater capital raising flexibility for smaller companies.

If there are valid investor protection reasons for current exemption requirements, those reasons should be on the public record for appropriate analysis. One may appropriately ask why the Commission has presented no policy justification for its refusal to increase the offering limits for Rules 504 and 505 and Regulation A, its failure to adopt a "no harm no foul" approach to offers but not sales made to unqualified offerees in intrastate and private offerings, its strict adherence to the numerical limits of Rules 505 and 506, its staunch silence in the face of constant criticism of its anti-solicitation rules, and the continuation of other exemption requirements that appear to have little bearing on investor protection. It has been over 30 years since the Commission undertook a serious study of small business capital formation needs and the impact of registration exemption requirements. Much has transpired in the interim, not least of which are the electronic communications revolution and increased resources to federal and state agencies to ferret out fraud and apply effective enforcement sanctions. The time is ripe for new examination and analysis of the interplay between investor protection and capital formation opportunities.

\section{The Commission May Believe that Modification of Federal Exemptions Would Be Ineffective in Light of State Regulations.}

State regulation is not well coordinated with federal exemptions and often renders such exemptions useless from the issuer's standpoint. Exhibit A to the lack of coordination is, aptly enough, Regulation A. Although Regulation A requires SEC filing and review of a disclosure document that is substantially similar to a registration statement, the federal exemption 
does not grant registration relief in most states. Most states require state registration of an offering exempt under Regulation $\mathrm{A}$, including audited financial statements that are generally not required by Regulation $A$ and constitute an important cost savings under the federal exemption. ${ }^{214}$ In addition to this incongruence, the SEC's 1992 adoption of a "testing the waters" concept for Regulation A offerings was met with a marked lack of enthusiasm, and some criticism, by state securities regulators. ${ }^{215}$ To date, only a minority of states have adopted regulations permitting the "testing of waters" in the absence of a prior state registration. ${ }^{216}$ Whatever benefits Regulation A provides to issuers at the federal level have thus been effectively emasculated by state regulation.

Similarly, even if the SEC eliminated from its exemptions the prohibitions against general advertising and solicitation, such elimination would not allow issuers ipso facto to engage in unrestrained marketing efforts within states. The ULOE exemption adopted in most states imposes Regulation D's antisolicitation prohibition, ${ }^{217}$ and it is questionable whether federal modification would cause state regulators to relax that requirement. State administrators may be more conservative than even the SEC in opening the door to broad solicitation efforts. ${ }^{218}$

In light of expected state antipathy to expanding exemption opportunities, it is reasonable to consider whether railing

214. Some states have created special provisions regarding the state registration of offerings federally exempt under Regulation A. See, e.g., Illinois Securities Law of 1953, 815 Ill. Comp. Stat. ANN. 5/5-B(1) (West 1999) (waiving the requirement for audited financial statements for Regulation $A$ offerings).

215. See 24 Sec. Reg. \& L. Rep. (BNA) 405 (March 27, 1992) (testimony of Arizona Securities Commissioner Dee Harris on behalf of North American Securities Administrators Association to Senate Banking Securities Subcommittee).

216. Arizona, Colorado, Indiana, Kansas, Kentucky, Massachusetts, North Dakota, Oregon, Pennsylvania, Utah, Vermont, Virginia, Washington, Wisconsin, and Wyoming, reported in 1 Stuart R. Cohn, Securities Counseling For Small And Emerging Companies, § 9:8, at 9-26 - 9-27 (West Supp. 2007).

217. See supra notes $169-170$ and accompanying text (discussing the Uniform Limited Offering Exemption ("ULOE")).

218. See supra Part III (Lack of Coordination With State Laws, regarding state administrator concerns). 
against SEC regulations is simply barking up the wrong tree, or worse yet, an inherently futile waste of time. The answer could be affirmative but for two important qualifications. The first is the potentiality of federal preemption. After over 60 years of concurrent federal-state regulation, Congress responded in 1996 to the lack of coordinated policy by creating a federal preemption against state registration or exemption provisions for so-called "covered securities," which include offerings made under the Rule 506 exemption. ${ }^{219}$ Pleas to expand the preemption to other federal exemptions are heard regularly from the SEC Small Business Forum participants. ${ }^{220}$ Preemption would take congressional action, and whether small business advocates have the political strength to overcome what is likely to be strong state opposition is uncertain. ${ }^{221} \mathrm{~A}$ second factor is the potential for modification of state exemptions. Local business interests and chambers of commerce have the ear of state legislators. Effective lobbying efforts may lead to a relaxation of state exemption requirements. In recent years, numerous states have adopted an accredited investor exemption that allows general advertising and solicitation in offerings re-

219. National Securities Market Improvement Act of 1996 ("NSMIA"), Pub. L. No. 91-190, §102(a), 110 Stat. 3416, 3417-19 (1996) (codified at 15 U.S.C. \$ 77r). In addition to Rule 506 offerings, covered securities include, inter alia, securities listed or authorized to be listed on a national securities exchange or NASDAQ's Global Market [and Capital Market B pending], a security of the issuer at least equal in seniority to a security exempt as a listed security, securities issued by companies registered under the Investment Company Act of 1940, and offers and sales to "qualified purchasers" as defined by the SEC (which thus far the SEC has declined to do). Id. at $\S 102(\mathrm{a})(\mathrm{b})$.

220. See, e.g., 1997 Final Report calling for federal preemption of Regulation A offerings (under "Securities Regulation"); the 1998 Final Report recommending federal preemption for Rule 505 and Regulation A offerings (under "Securities Regulation Recommendations"); the 1999 Final Report recommending that securities traded on the Nasdaq Small Cap market be included within "covered securities" (under "Securities Regulation Recommendations"); and the 2004 Final report recommending federal preemption for all small business offerings of $\$ 5$ million or less (Securities Regulation Recommendation \#16). Annual Final Reports may be accessed through the SEC's web site. See supra note 184.

221. State securities administrators have noted, through the North American Securities Administrators Association, their collective concern regarding the "negative effects" of federal preemption of state laws. State Securities Regulators Want Congress to Ensure Their Authority, 40 Sec. Reg. L. Rep. (BNA) 161 (Feb. 5, 2008). 
stricted to accredited investors. ${ }^{222}$ A number of states have created liberalized exemptions for local issuers, particular industries, or isolated offerings. ${ }^{223}$ Some states have waived their requirements for audited financial statements if the state registered offering is federally exempt under Regulation A. ${ }^{224}$ Pressures from the business community to modify state-imposed restraints on capital formation will undoubtedly continue at a pace no less than at the federal level. If the SEC were to undertake the study and evaluation recommended, leading to significant modifications to exemption requirements, there could well be added pressure on state legislatures to adopt further exemption modifications.

\section{B. Looking at Some Comparative Foreign Exemptions}

The concerns that restrain the SEC from creating greater capital formation opportunities for smaller companies, whatever they may be, are not shared in other countries with developed securities markets. Despite the fact that foreign countries frequently look to U.S. business and securities laws as models for adoption, the strictures imposed in this country on small business financing have not found favor elsewhere.

In the European Union, exemptions from the prospectus requirement most applicable to smaller companies are:225

(A) An offer made solely to qualified investors; ${ }^{226}$

222. See 1 Blue Sky L. Rep. (CCH) II 6471, at 2572 (2007) (listing states that have adopted NASAA's Model Accredited Investor Exemption).

223. Alabama, for example, has a local issuer exemption for offerings up to $\$ 500,000$, where no purchaser other than an accredited investor purchases more than $\$ 15,000$. There is no stated prohibition on advertising or solicitation. Ala. CODE § 8-6-11 (a) (14) (LexisNexis 2002).

224. See, e.g., Illinois Securities Law of 1953, 815 Ill. Comp. Stat. ANN. 5/ 5-B(1) (West 1999). The waiver of audited financials also applies to offerings exempt under Regulation D.

225. Council Directive 2003/71/EC, art. 3(2), 2003 O.J. (L 345) 64, 71, available at http://eur-lex.europa.eu/JOIndex.do?year=2003\&serie $=$ L\&text field2 $=345 \&$ Submit $=$ Search (last visited Nov. 4,2007 ). There are limitations on resales of securities so acquired where the resales could be deemed to be public offerings.

226. Qualified investors are defined more narrowly than the U.S. version of accredited investors. Natural persons qualify only if they meet two of the following conditions: (i) the investor has carried out transactions of a significant size on securities markets at an average frequency of at least 10 transactions per quarter for the previous four quarters; (ii) the investor's portfolio 
(B) An offer addressed to fewer than 100 natural or legal persons per Member state, other than qualified investors; or

(C) an offer with a total consideration of less than EUR 100,000 over a 12-month period.

There are no other conditions applicable to these exemptions. Although the exemption based on a EUR 100,000 ceiling (approximately $\$ 130,000$ under current exchange ratios) is low, many small companies in the U.S. would welcome the opportunity to engage in a condition-free offering for such amounts. We have not seen such an open-ended exemption since the early days of regulation. ${ }^{227}$ In contrast to SEC regulation, the EU's exemption based upon the number of offerees contains no personal qualifications, no specific disclosure requirements, the number limitation is only on a country-bycountry basis (and thus could result in a considerable number of purchasers), and, perhaps most significantly, there is no restriction on how purchasers can be solicited. To the contrary, the EU specifically allows a wide variety of advertising solicitation methods. ${ }^{228}$

The United Kingdom, although an EU member, has a distinctly different set of registration exemptions. "Exempt offers" in the U.K. include the following:

(1) Offers to no more than 50 persons within a twelve month period; 229

exceeds EUR 0.5 million (approximately $\$ 650,000$ under current exchange ratios); and (iii) the investor works or has worked for at least one year in the financial sector in a position that requires knowledge of securities investment. Id. at art. 2(2). Member states adopting the Directive can give greater definition to the "significant size" condition. Poland, for example, has defined that term to mean no less than EUR 50,000 per transaction. Act on Public Offering, Conditions Governing the Introduction of Financial Instruments to Organised Trading, and Public Companies, art. 8.2(1), Journal of Laws of 2005, No.184 item 1539 (July 29, 2005), available at http://www. kpwig.gov.pl/b_ang.htm (last visited Nov. 4, 2007).

227. See supra notes 66-72 and accompanying text.

228. Among the listed forms of permitted communication are addressed or unaddressed communications, electronic messages or advertisements received by mobile phone, standard letters, press advertising with or without order forms, seminars and presentations, radio, television, and web postings. Commission Regulation 809/2004, 2004, implementing Council Directive 2003/71 (EC), available at http://eur-lex.europa.eu/JOIndex.do?year=2004 \&serie $=$ L\&textfield2=149\&Submit=search.

229. Financial Services and Markets Act, 2000, c. 8, § 103(6), sched. 11 (Eng.), available at http://www.opsi.gov.uk/acts2000/00008-az.htm. 
(2) Offers to "a restricted circle of persons whom the offeror reasonably believes to be sufficiently knowledgeable to understand the risks involved in accepting the offer;" 230 and

(3) Offers involving no more than 40,000 Euros within a twelve month period. ${ }^{231}$

Many smaller companies in the U.S. would happily accept the 50-person limit, which comes with no strings attached such as purchaser qualifications or rules on how those persons are chosen for solicitation. Even the "restricted circle" exemption is far more generous for companies insofar as it does not, unlike in the U.S., require that members of that circle be previously known 'to the issuer or issuer's agents. ${ }^{232}$

South America's largest capital market, Brazil, provides a registration exemption for "empresas de pequeno porte," small companies whose annual gross revenues do not exceed $\mathrm{R} \$ 2.4$ million (equivalent to approximately $\$ 1.2$ million under current exchange rates). ${ }^{233}$ It is easy to contrast this exemption with the $\$ 1$ million U.S. exemption, Rule 504, which is replete with limitations on advertising and solicitation waived only if the offering is state registered or made pursuant to a state accredited investor exemption.

Exemptions developed for smaller companies elsewhere in the world are probably not attributable to any greater faith in foreign countries in the integrity of small companies but rather to a cost-benefit analysis measuring the capital needs of smaller companies with the risks of offering abuses. In the absence of most of the U.S.-type conditions governing exempt offerings, there appears to be a greater reliance in foreign countries on post-offering remedial actions. This analysis con-

230. Id. at $6(1)$.

231. Id. at $9(1),(2)(\mathrm{b})$.

232. The limited exemptions afforded by the United Kingdom and the European Union have also been criticized for their lack of attention to small business capital requirements. Hse-Yu Chiu, Can UK Small Businesses Obtain Growth Capital in the Public Equity Markets? Can Overview of the Shortcomings in UK and European Securities Regulation and Considerations for Reform, 28 DEL. J. CorP. L. 933, 935 (2003) ("The highly regulated public equity market is deterring to small issuers because of the high cost of compliance as compared to their relatively small issues.").

233. Art. 5, § III, Instrucao CVM 400/03, de 29 de dezembro de 2003. Empresas de pequeno porte are defined in Complementary Law No. 123 (Dec. 14, 2006). 
tains enormous irony, for the one thing that U.S. securities laws are most known for is the effective public and private enforcement processes ranging from administrative to civil to criminal sanctions. Yet, the SEC remains reluctant to rely significantly on post-offering remedies when it comes to small company issuers.

V.

\section{PART V: RECOMMENDATIONS FOR REFORM}

\section{A. Where We Are Today: In Need of Rational Regulation}

Small businesses depend on multiple rounds of financing to develop new products and services and to expand their marketing opportunities. The ability to access the public markets for capital is affected by numerous factors, the timing and scope of most of which are beyond the control of the particular small business issuer. Capital market "windows" often are brief in duration, and smaller companies do not have the ability, as do larger ones, to take advantage of favorable conditions by quickly developing a registration statement. Nevertheless, difficult market conditions may present business opportunities for smaller companies. The airline industry is one example of how new companies, unburdened by legacy costs, can penetrate a key business segment. Difficult economic times can provide significant opportunities for companies that can nimbly fill a gap or capitalize on an emerging technology. A registered public offering does not provide the clearest capital path for many smaller companies in this situation. A quick capital raise, outside the registration process, is often precisely what the smaller companies need. Unfortunately, Byzantine regulations often render registration exemptions unavailable. The result is stifled innovation and loss of business opportunity.

Venture capital financing is one avenue open to companies that do not have ready access to public capital and institutional financing. In 2007, $\$ 29.4$ billion of private venture capital funded over 3500 companies at an average investment of $\$ 7.73$ million. ${ }^{234}$ These statistics are impressive, but they mask

234. Money Tree Report by PricewaterhouseCoopers and National Venture Capital Association, http://www.nvc.org/ffax.html, https://www.pwc moneytree.com/MTPublic/ns/index.jsp. 
the fact that only a very small percentage of applicants receive venture funding, and companies that need relatively small amounts generally cannot get onto a venture capital company's radar screen.

Growth capital for small businesses remains scarce, due in large part to the inability of small businesses to connect directly with funding sources. The internet is not a door to funding sources due to the restrictions on general solicitation for most private offerings. The regulatory scheme governing exempt offerings has been largely unchanged for 25 years, with drastic results for smaller businesses. Now is the time to modernize the regulatory landscape, acknowledge the changes that modern information and communications technologies have wrought and remove the impediments to capital raising for smaller businesses. We believe this can be done without sacrifice to investor protection.

\section{B. Reform Recommendations}

Although there are numerous specific problem areas within each registration exemption that could be addressed on a piecemeal basis, we recommend that the Commission capitalize on the momentum of its August 2007 Release to undertake more comprehensive measures to assist small business financing. To accomplish this, we suggest the following:

\section{Task Force on Small Business Capital Formation}

Our principal recommendation is that the SEC establish a broadly representative task force on small business capital formation to examine whether and to what extent current laws and regulations impede small business financing and determine recommendations for improving financing capabilities under the federal and state securities laws. The task force should include representatives of small business, state securities administrators, self-regulatory organizations, American Bar Association committees, broker-dealers, the accounting profession, and others from both the public and private sectors who would have relevant input. The SEC has not undertaken a comprehensive study of small business concerns for 
nearly 30 years, ${ }^{235}$ an extraordinarily long period of time given the changes in financial markets and technologies.

\section{Recommendations Regarding Special Areas of Concern}

Without intending to limit the scope of the proposed Task Force's examination, we would recommend that the following issues be considered:

(a) Enact Broader Federal Preemption of State Registration and Exemption Laws. Reform of federal exemptions will be without significant effect unless such exemptions can be utilized under state laws. Congress took the first steps towards preemption in $1996,{ }^{236}$ and the ability of issuers to avoid state registration requirements through Rule 506 has not appeared to create serious state law risks. States should remain able to police offerings, issue stop orders, and impose administrative and criminal penalties through their disclosure standards, while allowing issuers who meet federal exemption requirements to offer and sell securities without state registration or exemption conditions. Expanding federal preemption to all exemptions from registration, except perhaps the intrastate exemption, would be among the most significant measures that could be taken for small businesses. Assuming that adequate disclosure standards are imposed, and antifraud provisions remain at both the federal and state levels, preemption would not, in our judgment, impair investor protection concerns.

(b) Place Greater Reliance on Disclosure and Antifraud Sanctions. We believe that the dual concerns of investor protection and small business financing can best be accommodated through clear disclosure standards mandated for all federal exemptions. We propose elimination of many of the current technical exemption requirements in favor of a disclosure regime that is both adequate and enforceable. In this regard, we support a disclosure program for all investors, including accredited investors, whatever the monetary amount of the offering. If issuers are seeking capital from investors, a minimum disclosure obligation should exist regarding company and

235. Examination of the Effects of Rules and Regulations on the Ability of Small Business to Raise Capital and the Impact on Small Business of Disclosure Requirements Under the Securities Act, Securities Act Release No. 5,914, 42 Fed. Reg. 64,163 (Mar. 6, 1978).

236. See supra note 166. 
management information, use of proceeds, financial statements, and offering risks. A mandatory disclosure requirement would be consistent with protection of investors as well as provide issuers a measure of protection from Rule $10 \mathrm{~b}-5$ and other disclosure-related liabilities. By restricting its representations to those contained in a disclosure document, the issuer retains control over representations that are made and has the opportunity to ensure that all material information is fully and fairly presented to prospective investors. Further, the rigorous review procedure employed to draft a disclosure document provides assurance that essential information is conveyed to prospective purchasers of securities.

(c) Eliminate Restraints on General Solicitation and General Advertising. Prohibitions on general solicitation and advertising should be eliminated. Investor protection should be much more concerned with what is said, rather than to whom or in what manner the disclosure is made. Antifraud standards can effectively replace the anti-solicitation regulations and would apply on a case by case basis to circumstances where disclosure is misleading or inadequate, or where the issuer is or should be aware that the particular investor lacks the capacity to understand the disclosures.

(d) Narrow the Definition of "Offer". Initial contacts by issuers and their agents, and limited advertising materials, should not be treated as "offers" for securities law purposes if the potential investors cannot purchase any securities until after they are provided with appropriate disclosure documents and subscription agreements. In view of the telecommunications and media revolution, the SEC should recognize that it is both unrealistic and unnecessary to restrict communications in connection with exempt offerings. Therefore, the SEC should define "offers" consistent with traditional concepts of contract law and eliminate restrictions on early-stage advertising or generalinterest type announcements.

(e) Eliminate or Substantially Limit the Integration and Aggregation Doctrines. The continued need for the integration doctrine should be closely examined. We believe each offering should be allowed to stand on its own with regard to compliance. Misuse or abuse of exemption conditions can be handled on a case by case basis without resort to an integration doctrine. If the integration concept is to be retained, the safe harbor time frame should be reduced to 30 days for all exempt offerings 
subject to instances of clear abuse. Similarly, we recommend elimination of the analogous aggregation doctrine. Where an offering meets all exemption conditions, a subsequent offering meeting all exemption conditions should not be integrated or subject to aggregation except in clear cases of abuse.

(f) Carve Back Substantially the "Sophistication" Requirement for Private Offerings. The "sophistication" required under Section 4(2) of the 1933 Securities Act and Rule 506 creates significant concern because the standard is ambiguous and, as interpreted by the SEC, too strict. Offerings should be permitted to be made to all persons capable of understanding and evaluating the disclosures. We are concerned that proposed Rule 507, which will require prior investment experience, is a step in the wrong direction. There is no justification in our judgment for prohibiting persons of ordinary intelligence, who have the right today to invest in registered offerings, from investing in exempt offerings for which adequate disclosure has been made.

(g) Eliminate Issuer's Potential Loss of Exemption By Reason of Unforeseen Resales. If the issuer has made a good faith attempt to limit resales, an exemption should not be lost by reason of untimely resale or resale to an ineligible purchaser. This recommendation assumes that some form of "restricted securities" will survive as a condition for various exemptions, an issue that itself deserves further study as to whether such restrictions are in fact necessary for investor protection purposes.

(h) Increase Exemption Ceilings. If it is considered appropriate to retain a monetary ceiling on some exemptions, itself a debatable point, current ceilings should be substantially increased. The SEC's recently-enacted authority to create exemptions under Section 28 of the 1933 Securities Act permits the Commission to avoid Section 3(b)'s $\$ 5$ million monetary ceiling should the Commission choose to act without further legislative authorization.

(i) Modify the "Doing Business" Standards of the Intrastate Exemptions. The $80 \%$ standards in Rule 147 have become anachronistic in these days of global business and communications. If the intrastate exemption continues to have a "doing business" requirement, it should be reduced to a principal place of business test. 
(j) Eliminate or Substantially Increase the Numerical Limits on Purchasers. The 35 person limitation on non-accredited investors in Rule 505 and Rule 506 should be eliminated or substantially increased. The number is arbitrary and restrains companies from marketing securities to more than a relatively few investors who do not meet the accredited investor standard. The limitation may also preclude a company from offering shares to its employees or seeking investments from customers and others interested in the issuer's products or services. The numerical limitation also creates unnecessary regulation in the context of mergers and other corporate reorganizations. Except where Section 3(a) (11) or Rule 147 may apply, a registration statement is necessary to effect an ordinary corporate transaction in which stock is used as consideration if there are more than 35 unaccredited investors in the target company.

(k) Implement Rules Permitting Private Placement Brokers and Finders. Even though many Blue Sky laws limit the payment of commissions or other compensation to registered securities intermediaries, there are literally thousands of "finders" and other persons willing to match private investors and smaller companies for a fee, typically contingent on a successful investment and the amount of funds raised, who are not registered as broker-dealers with the FINRA or the states in which they operate. ${ }^{237}$ We believe the SEC, as recommended by its own Advisory Committee on Smaller Public Companies, should spearhead a reform effort among the FINRA and the states to provide a simplified registration process and on-going regulatory oversight better adapted to the limited nature of the business of private placement brokers.

\section{VI. \\ ConClusions}

As critics of the current scheme of registration exemptions, we are both discouraged and hopeful. After a quarter century of neglect, the SEC has finally turned its attention to the serious impediments to capital formation created by its regulations and interpretations. We are discouraged because,

237. E.g., Uniform Limited Offering Exemption, § 1.A ("No commission, fee or other remuneration shall be paid or given, directly or indirectly, to any person for soliciting any prospective purchasers in this state unless such person is appropriately registered in this state."). 
despite the rhetoric in recent years, the door has opened only inches and not nearly enough to provide effective assistance to smaller businesses with capital needs. ${ }^{238}$ We are hopeful because the path to reform is clear. We have proposed a set of recommendations that we believe are consistent with investor protection concerns. The notion that, in an internet world, potential investors can be hidden beyond the reach of peddlers of fraudulent securities is obsolete. We do not believe, however, that the specter of unscrupulous fraudsters preying upon innocent investors justifies the unnecessarily burdensome regulation which currently hamstrings new and growing companies. When one of the authors of this article was an SEC staff member, the hallway admonition was to protect "the little old lady in tennis shoes." That investor and all others deserve regulations that require full and comprehensible disclosure and provide for adequate means to enforce violations of those provisions. We believe that it is better to base a regulatory format on disclosure and antifraud provisions rather than restrictive exemption conditions that severely hamper financing capacities. Government resources expended for unnecessary regulation could be better employed, we propose, for enforcement purposes.

238. SEC Commissioner Atkins conceded the need to do more in his remarks during the SEC Open Meeting on May 23, 2007, in connection with the Commission's rulemaking proposals to address small business capital raising activities. Commissioner Atkins notably made the following observation:

I mentioned that these proposals make an excellent start because I do not believe that the Commission's work in this area is going to be finished after today or even after we adopt these particular sets of proposals. Our proposals do not address other issues brought up by the Advisory Committee, the forum, or the $A B A$, such as finders and private placement broker/dealers, expanding and testing the waters provision that we first put in back in the early 1990s, clarifying the definition of "control" for certain purposes, or revising Rules 504 and 505. I think more work needs to be done by the Commission to achieve an optimal level of investor protection and capital formation for smaller companies. The staff has only been significantly engaged on these rulemakings since the beginning of this year. I would encourage you all to continue your fine work in this area and present some additional ideas. I look forward to seeing this during the year.

Unofficial transcript of the May 23, 2007 (emphasis added), SEC Open Meeting available at http://www.sec.gov/news/openmeetings.shtml. 
The dual goals of capital formation and investor protection are not mutually exclusive. Each can be accomplished without diminishing the other. Although we have proposed a number of specific recommendations, we believe that the starting point should be a comprehensive review of the registration and exemption structure, including the impact of dual federalstate regulation. The agenda is transparent - create a unified regulatory system for limited offerings of securities which encourages investment in small business and protects those who so invest. Implementation cannot happen overnight or without some political confrontation and pain, but the issues are clear. In a fast-changing and increasingly global financial marketplace, the SEC is the logical, in fact the only, regulator that can lead the effort for meaningful change. It is charged to do so, and we are hopeful that the Commission will accept the challenge. 
Imaged with the Permission of N.Y.U. Journal of Law and Business HeinOnline -- 4 N.Y.U. J. L. \& Bus. 88 2007-2008 